\title{
Geology of the
}
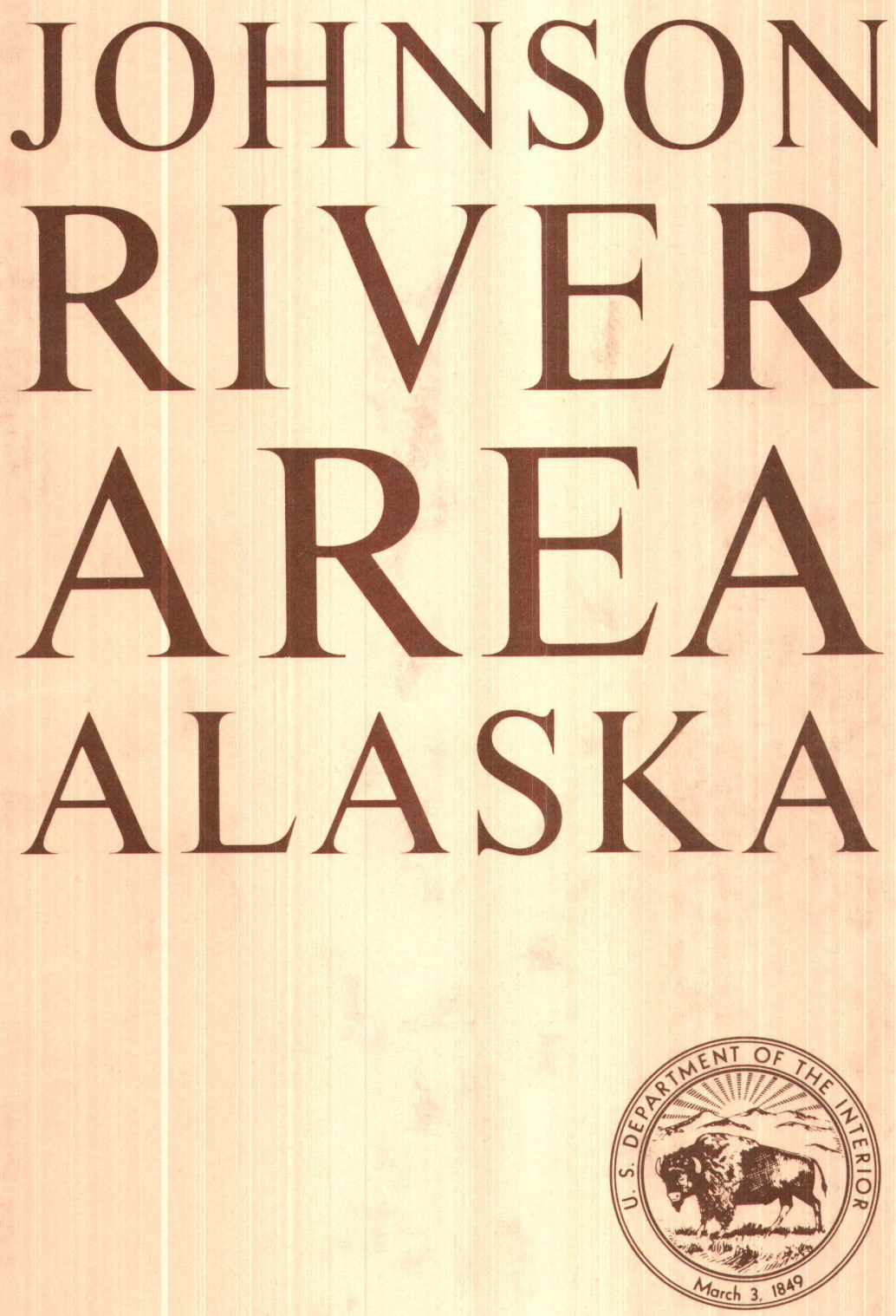

GEOLOGICAL SUR VEY BULLETIN 1249 

JOHNSON RIVER AREA, ALASKA 



\section{Geology of the}

Johnson River Area

Alaska

By G. WILLIAM HOLMES and HELEN L. FOSTER

G E O L O G I C A L S U R VEY B U L L E T I N 1249

An account of surficial and bedrock geology of a representative area in east-central Alaska

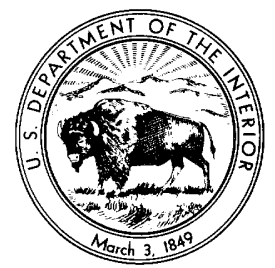

UNITED STATES GOVERNMENT PRINTING OFFICE, WASHINGTON : 1968 


\section{UNITED STATES DEPARTMENT OF THE INTERIOR}

STEWART L. UDALL, Secretary

\section{GEOLOGICAL SURVEY}

William T. Pecora, Director

Library of Congress catalog-card No. GS 68-214

For sale by the Superintendent of Documents, U.S. Government Printing Office Washington, D.C. 20402 


\section{CONTENTS}

Introduction

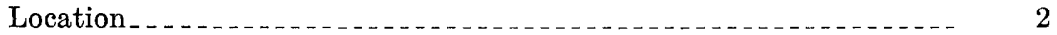

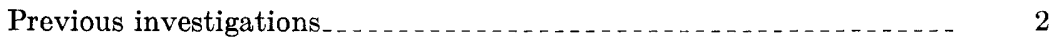

Present investigation

Geography . . . . . .

Relief and drainage

Yukon-Tanana Upland .

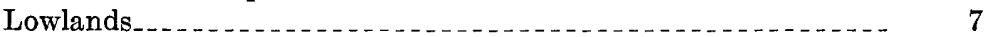

Alaska Range.

Climate.

Vegetation

Permafrost. . . . .

Settlements and transportation 12

Bedrock geology

General features...

Metamorphic rocks 13

Occurrence and description

Minor structures and metamorphic grade

Age

Igneous rocks_............. 16

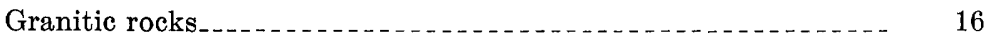

Distribution and description.

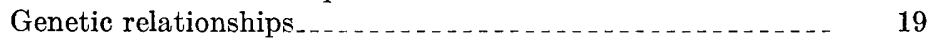

Contacts.

Age...... 21

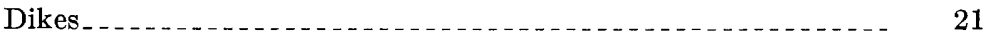

Structural relationships and faults $\ldots \ldots \ldots \ldots \ldots$

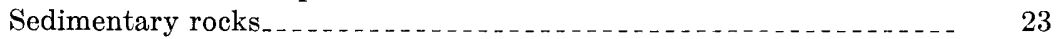

Carbonaceous silt and clay .............................. 23

Nenana Gravel

Glacial geology

Deposits of the Delta Glaciation .......................... 26

Deposits of the Donnelly Glaciation . 30

Deposits of Recent glaciers . 33

Frost action and mass movement

Rock glaciers . . .

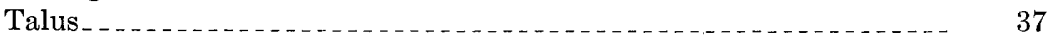

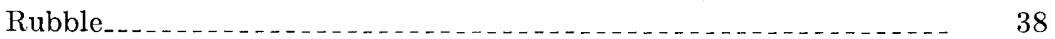

Colluvium _............. 39

Pingos.

Patterned ground 


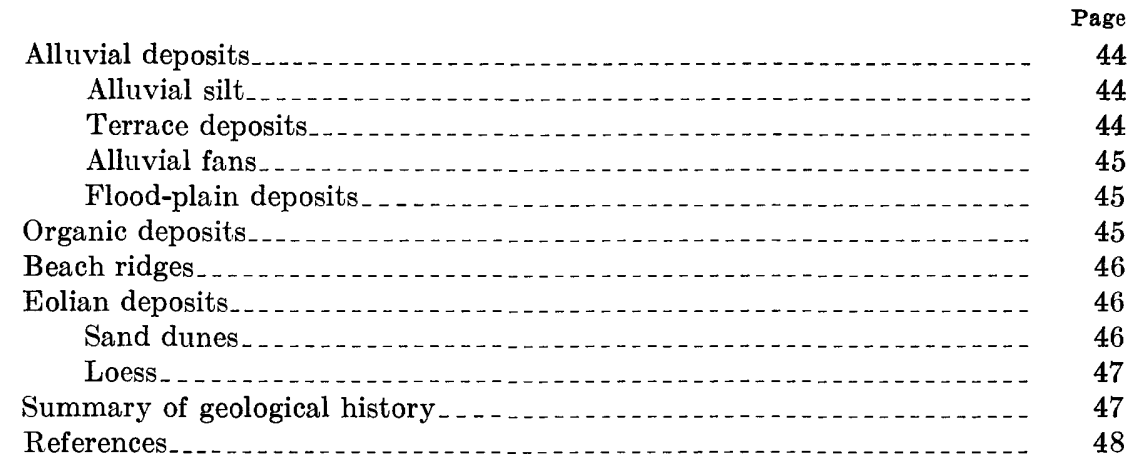

\section{ILLUSTRATIONS}

Frontispiece. Long, tongue-shaped rock glacier in the upper Johnson River area.

Plate 1. Geologic map of the Johnson River area, Alaska _..... In pocket FIgURE 1. Location and physiographic maps of the Johnson River area.--

2-15. Photographs showing-

2. Oblique aerial view of the lower Johnson River

3. Oblique aerial view of the upper Johnson River

4. Shattering in granodiorite

5. Jointing in granodiorite

6. Horn Mountain

7. Carbonaceous silt and clay deposits

8. End moraines between the Gerstle and Little Gerstle Rivers.

9. Ice-contact ridge on Macomb Plateau

10. Donnelly end moraine on Dry Creek

11. Oblique aerial photograph of Recent moraines and rock glaciers

12. Panorama of Recent moraine at the head of Bear Creek

13. Crescentic ridges and furrows

14. Moving front of the large rock glacier.......

15. Circular cratered pingo east of Sand Lake.....

16. Sketch showing cross section of the pingo east of Sand Lake....

17. Photograph showing net of segregated boulders in till....... 


\title{
GEOLOGY OF THE JOHNSON RIVER AREA, ALASKA
}

\author{
By G. William Holmes and Helen L. Foster
}

\begin{abstract}
The vegetation, topography, and geology of the Johnson River area are representative of the entire eastern interior region of Alaska. This area has a vegetational cover of both boreal forest and upland tundra, has a continental subarctic climate, and is within the zone of discontinuous permafrost. The topographic units include the rolling hills of the Yukon-Tanana Upland, the terraces and moraines on the Tanana-Kuskokwim and Northway-Tanacross Lowlands, and the rugged peaks and deep canyons of the Alaska Range.

The bedrock is composed mostly of metamorphic and igneous rocks. The metamorphic rocks, largely schist and gneiss, have been profoundly deformed and are possibly Precambrian in age. Quartzite, hornfels, and amphibolite are minor constituents of the metamorphic complex. The metamorphic rocks have been invaded by granitic rocks of Cretaceous age, and dikes of several ages cut both the metamorphic and igneous masses. Contacts between the igneous and metamorphic rocks include contact breccias, crosscutting intrusive contacts, and a contact zone of mixed igneous and metamorphic rocks. Although the granitic rocks include granodiorite, granite, quartz monzonite, quartz diorite, and diorite, similarities in mineral and chemical composition of representative rocks and similarity in the absolute age of scattered specimens suggest that they are genetically related and probably part of a single pluton. Lead-alpha age determinations were in close agreement and ranged from 90 to $110( \pm 10)$ million years.

Very small deposits of Tertiary carbonaceous silt and clay and Tertiary gravel occur in the foothills of the Alaska Range. The former deposits contain a pollen flora transitional between the warm-temperate forest of the early and middle Miocene and the boreal forest of the Pleistocene.

Pleistocene glaciation of the Alaska Range was intense and produced a variety of glacial forms, including long valley glaciers, icecaps, outlet glaciers, and cirque glaciers. The older advance has been correlated with the Delta Glaciation of the Delta River area and resulted in broad high-level icecaps as well as long valley glaciers that extended to the Tanana Lowland. Broad sheets of gravel were deposited during the Delta advance and formed fan aprons and terraces on the lowland. A later advance that has been correlated with the Donnelly Glaciation was as extensive in the main valleys but did not form icecaps so numerous or so large as those of the Delta Glaciation. The retreat of the Donnelly ice was interrupted by short pauses or readvances in some of the higher valleys; during its final decay, deep canyons were carved in Delta till.
\end{abstract}

Eolian activity was probably at a maximum during and immediately following glacial advances when the supply of silt and sand was abundant and vegetational cover was sparse. Thick deposits of loess covered the hills and terraces along 
the Tanana River, and large, scattered sand dunes accumulated. Similarly, formation of patterned ground, talus, rubble, and colluvium was greater during periods of glacial climate. Phenomena of Recent age such as small end moraines and rock glaciers and pingos possibly reflect climatic fluctuations since the last major glaciation. On the other hand, terrace, flood-plain, alluvial-fan, alluvialsilt, and organic-silt deposits, although important elements in the landscape, do not appear to reflect climatic events so distinctly as glaciations or related phenomena.

\section{INTRODUCTION}

\section{LOCATION}

The Johnson River area, in east-central Alaska, is about 150 miles west of the Canadian border, about 245 miles north of the Pacific coast, and about 150 miles southeast of Fairbanks (pl. 1). The mapped area coincides with the U.S. Geological Survey Mount Hayes C-1 and C-2 quadrangles and the south half of the Mount Hayes D-2 quadrangle and covers about 710 square miles (pl. 1). Parts of the Alaska Range, the Tanana-Kuskokwim Lowland, and the Yukon-Tanana Upland constitute this area (fig. 1) that is named for the short, broad river that flows northward from the Alaska Range to join the Tanana River in the Mount Hayes C-2 quadrangle.

\section{PREVIOUS INVESTIGATIONS}

The earliest major geological reconnaissance of the Johnson River area was made under the leadership of Brooks (1900), who explored the Tanana River valley in 1898. Subsequently, numerous investigations were made in the Alaska Range and in the Yukon-Tanana Upland; these are summarized in two principal publications. Mertie (1937) presented his work and that of several others, including Brooks, in a comprehensive publication on the Yukon-Tanana Upland. Moffit's work of more than 30 years in the Alaska Range and adjacent areas appears in short publications as well as in an excellent treatise on the region (Moffit, 1954). Recently, detailed work has been completed by Péwé and Holmes in the Delta River and Gerstle River areas (fig. 1), and reconnaissance studies have been made by Holmes along the Alaska Highway from Delta Junction to Tok Junction (Péwé, 1952; Péwé and others, 1953; Holmes and Benninghoff, 1957; Péwé and Holmes, 1964; Holmes and Péwé, 1965; Holmes, 1965; Foster and Holmes, 1965).

\section{PRESENT INVESTIGATION}

Scope of report.--This report is based on studies of the surficial deposits and reconnaissance mapping of bedrock of the Johnson River area; the investigations were a part of more extensive fieldwork on 


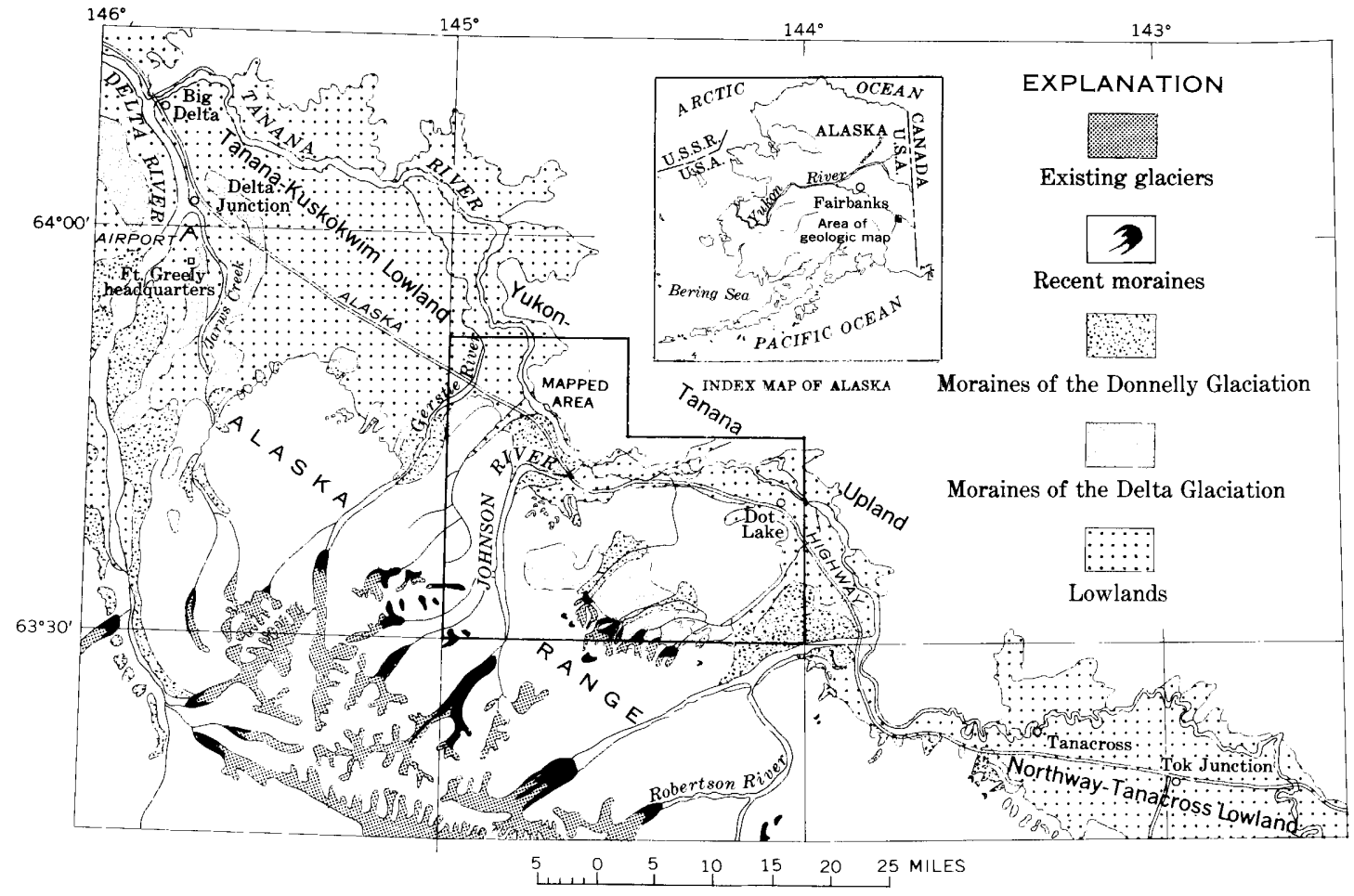

Figure 1.-Location and physiographic maps of the Johnson River area. 
the surficial depasits in the surrounding region. Distribution of the geologic units is shown on the accompanying map (pl.1). The section on bedrock geology includes a brief discussion of the metamorphic and igneous rocks that underlie the area, as well as a description of younger units of limited extent; emphasis was on mapping the surficial deposits and determining the Quaternary history of the area.

Fieldwork.-The principal field studies were made in the summers of 1957 and 1960. Six months were spent on fieldwork, about 1 month of which included bedrock mapping. Mapping was done on aerial photographs (scale $1: 50,000$ ) and on enlarged topographic base maps (scale $1: 40,000)$. Most of the mapping was done on foot; many different camps, established by floatplane or helicopter, served as bases for fieldwork in the hills and mountains. Several traverses were made by automobile along the Alaska Highway, which runs from northwest to southeast through the area, by boat along the Tanana River and its tributaries, and by tracked vehicles in a few areas west of the Johnson River. Preliminary reconnaissance and subsequent observations were made from light aircraft and helicopters.

Acknowledgments.-The fieldwork was done in connection with the study of Alaskan terrain and permafrost and was financed to a large degree by the Engineer Intelligence Division, Office of the Chief of Engineers, U.S. Army. Local support was provided by the U.S. Army Cold Weather and Mountain School and the U.S. Army Arctie 'Test Board, both at Fort Greely, about 45 miles west of the area. The writers are especially grateful to numerous members of the Armed Forces at Fort Greely for their provision of administrative services, aircraft, tracked vehicles, boats, and medical facilities.

The senior author was accompanied in the field in 1957 by H. B. Groom, Jr., geologist, and L. A. Spetzman, botanist; the junior author was assisted in 1961 by Mona Goranson. Dr. Robert Forbes of the University of Alaska examined and analyzed rock thin sections and specimens. The contributions of these coworkers are acknowledged with sincere gratitude.

\section{GEOGRAPHY}

The area includes rolling hills of moderate height, a narrow alluvial lowland, extensive foothill ridges and plateaus, and rugged glaciercovered mountains (figs. 2 and 3). Altitudes range from about 1,200 feet in the northwest to nearly 8,000 feet in the south-central sector. The area is drained by the Tanana River and its tributaries.

The climate is cold and dry in the winter and warm and moist to dry in the summer. No weather records have been kept in the area, but at the Federal Aviation Agency station near Fort Greely, 45 miles to the 


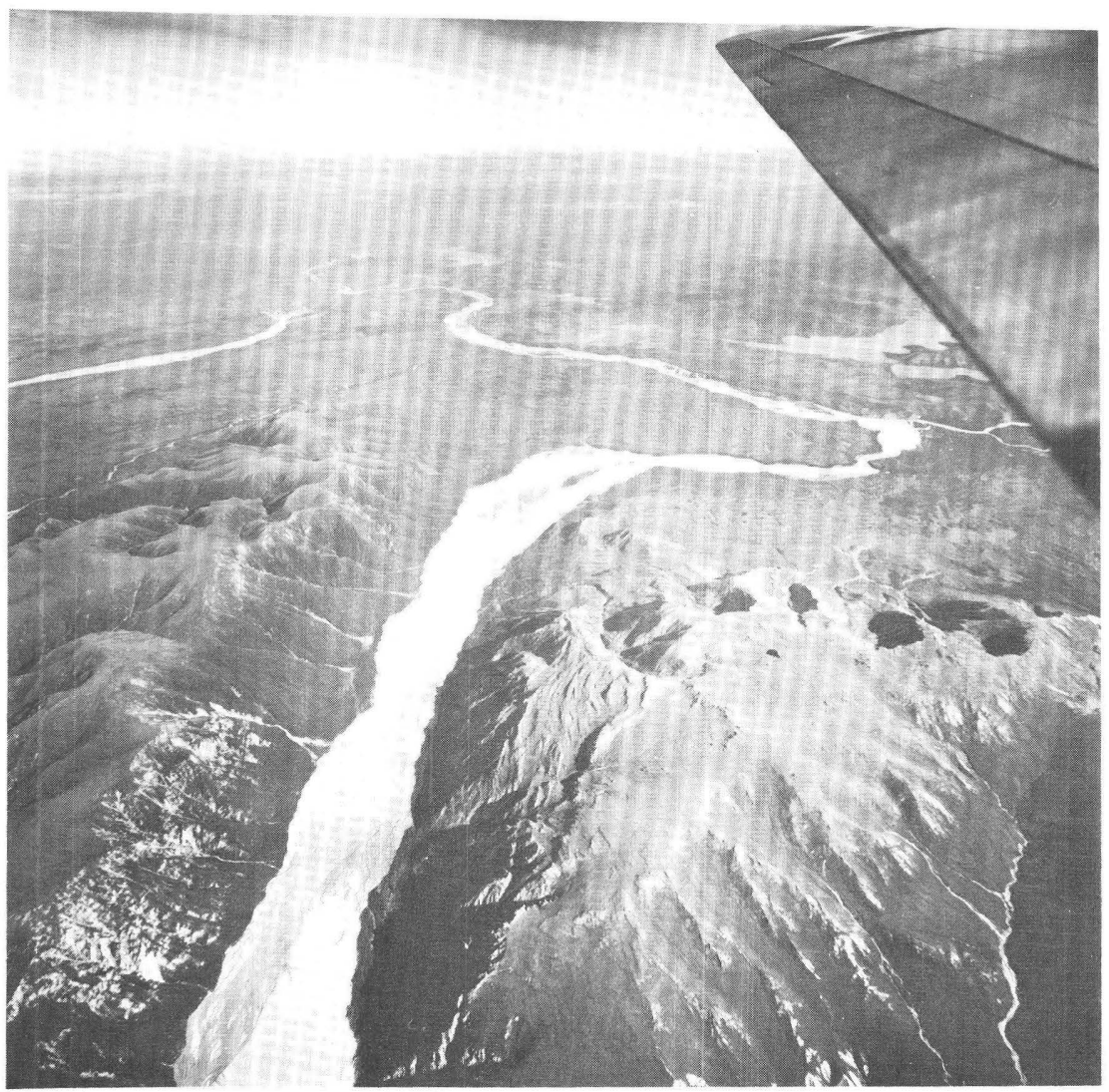

Figure 2. Oblique aerial view of the lower Johnson River. Independent Ridge is on the left; Horn Mountain, right, is a dissected upland with its northern edge scalloped by cirques. The large Johnson River moraine of the Donnelly Glaciation deflects the lower Johnson River in its lower course. The Tanana River, with Lake George beyond, and the Gerstle River, on the left, appear in the distance. View to the north. U.S. Army Air Force photograph, 1941, taken before the construction of the highway and bridge.

west, the mean annual temperature is $27.6^{\circ} \mathrm{F}$ and the mean annual precipitation is 11.63 inches. The area is in the zone of discontinuous permafrost. Vegetation includes boreal forest and marsh, bog and muskeg, and tundra plants. Tree line ranges from about 2,500 to 3,500 feet. The population is very sparse; most inhabitants live near Dot Lake.

\section{RELIEF AND DRAINAGE}

The mapped area includes small parts of three physiographic provinces: the Yukon-Tanana Upland, the Tanana-Kuskokwin Lowland, and the Alaska Range (fig. 1). The terrain of each of these physio- 


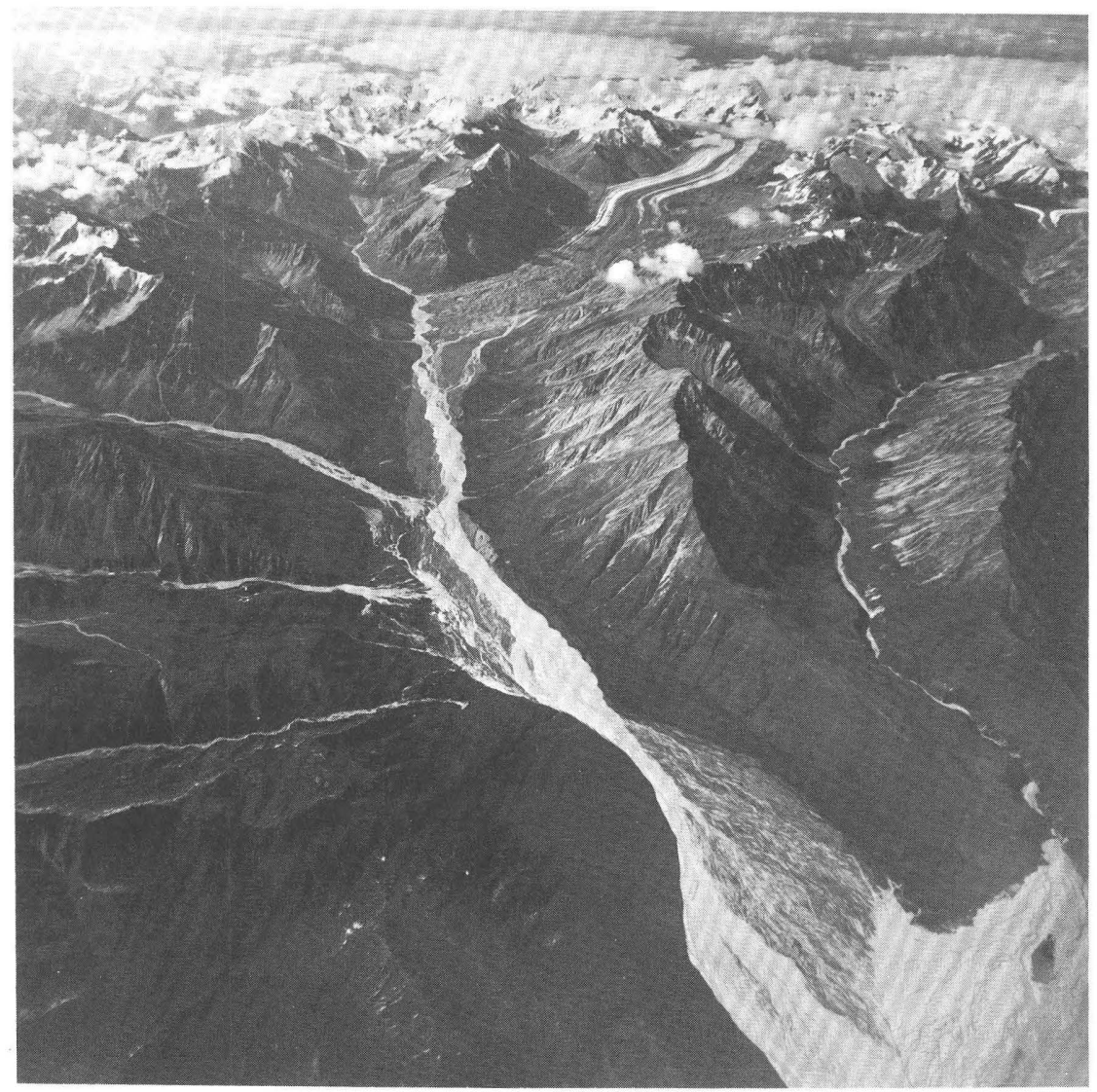

FIgURE 3. Oblique aerial view of the upper Johnson River. The southern boundary of the map area crosses the photograph from left to right in the middle distance. The large Johnson River glacier in the distance is a relic of one of several Pleistocene glaciers that covered much of the mapped area. Large alluvial fan was derived from the erosion of a deep branched valley in the left foreground. View to the south. U.S. Army Air Force photograph, 1941.

graphic units in the mapped area is generally typical of the corresponding units as a whole.

\section{YUKON-TANANA UPLAND}

The Johnson River area covers a small section of the south edge of the Yukon-Tanana Upland, a large region of moderate to high, rolling, loess-covered bedrock hills and low mountains. In the mapped area, slopes are moderate to steep (1,000 to 1,500 feet), and summit altitudes are 2,000 to nearly 3,000 feet above sea level. Drainage patterns are very irregular, reflecting both the structural trends and the outlines of drainage systems of the past. Streams in this unit of the mapped area 
are small, sluggish, and commonly discolored by organic material. Their sources are snowmelt, rainfall, and thawed seasonal frost. These streams have a high stage during snowmelt and may be high later for short periods after unusually heavy rains, but even in normal years many of the smaller streams are dry in July and August. The larger of these streams-George, Sand, and Billy Creeks (pl.1) - are navigable by shallow-draft boats for short distances during normal and high stage. Muskeg and bog vegetation is common in the valleys through which these small streams flow.

The largest lakes in the mapped area lie in basins in the YukonTanana Upland; the lakes typically are enclosed on three sides by bedrock hills and on the fourth side by alluvium of the Tanana Lowland (pl. 1). They range in size from about 1.3 miles to 5 miles in maximum dimension. Precise depth data are lacking, but Lake George is probably no deeper than about 55 feet, whereas Sand Lake is no deeper than about 10 feet. The larger lakes, Twelvemile, George, Moosehead, Black, and Sand, are suitable for landings by light aircraft on floats in the summer and on skis in winter. Maximum ice thickness averages slightly more than 3 feet and varies according to snow cover. Although all these lakes are fed by sluggish streams having a high organic content, the lake water is fairly clear. The lakes have a high population of plankton and other small organisms, including crustaceans, leeches, and worms. These in turn support a substantial population of pike, ling cod, whitefish, and aquatic birds. The lakes are rimmed at several places by ice-pushed ridges of clean gravel or of silt and peat deposits, by foul-smelling organic-silt flats and marshes, by clean sandy beaches, or by rocky bluffs.

\section{LOWLANDS}

The mapped area includes the west extremity of the NorthwayTanacross Lowland and the east end of the Tanana-Kuskokwim Lowland. These lowlands together extend from the Canadian border, westward in an arc along the north flank of the Alaska Range and are separated by a narrows near the center of the mapped area (Wahrhaftig, 1965, pl. 1). The lowlands are filled with glacial and nonglacial alluvium and are covered in places by piedmont moraines. The unit in the mapped area is relatively narrow but is typical of much of the physiographic provinces as a whole. It is bordered in places on the northeast by steep bluffs of the Yukon-Tanana Upland, which rise as much as 1,500 feet above the lowland. Scattered low rounded bedrock hills, not more than about 700 feet high, rise above the alluvial deposits. On the south the lowland includes moraines having relief of about 200 feet; it is bordered by bedrock hills having relief of 500 to 600 feet. The lowland is about 1,200 to 1,700 feet above sea level. The alluvial floor 
is incised by the Tanana River and its tributaries to depths ranging from 4 to about 75 feet. It is also marked by meander scars, pond depressions, and sand dunes not more than about 30 feet high. Bogs and muskegs, ranging from a few feet to more than 9 miles in length, are very common.

The glacier-fed Tanana River is a large braided moderately swift stream. Streamflow records from the nearest stations upstream at Tanacross and downstream at Big Delta (U.S. Geological Survey, $1957,1958 \mathrm{a}, 1958 \mathrm{~b}, 1960)$, give a general view of the regime of the Tanana River in the mapped area (fig. 1). Low discharge occurs in February or March; discharge then gradually increases until May at breakup time. Unlike the Yukon River, the Tanana here does not experience catastrophic floods at breakup time, because iceblock dams normally do not form. After breakup, discharge increases rapidly, reaching a peak in July or August, a time of maximum glacial melt and rainfall. Maximum discharge at this time is commonly about 10 times the minimum flow in late winter. Streamflow decreases rapidly in September because of freezeup, and gradually decreases through the winter.

Ice cover in the Tanana River in midwinter is probably about 3 feet thick, but in many places it is much thinner or absent. Locally, ice may be thicker than 3 feet, usually as a result of overflow icing. The stream is heavily laden with glacial, eolian, and alluvial silt from early June through September. Large quantities of driftwood are carried by the stream owing to undercutting of the heavily forested banks. The river is navigable by boats having a shallow draft, stability, good maneuverability, and powerful retractable motors.

\section{ALASKA RANGE}

The Alaska Range, the highest and one of the longest mountain regions in Alaska, includes such features as foothill plateaus, deep canyons, steep-sided cirques, sharp peaks, and active glaciers; all are present in the Johnson River area. The mountains are composed of metamorphic and igneous rocks, mantled by various thicknesses of alluvium, colluvium, and drift. Relief ranges from about 700 feet in the lower foothills to about 3,500 feet in the higher sections to the south; altitudes range from about 2,000 feet along the north edge to nearly 8,000 feet in the upper Johnson River area. Although the area is characterized by steep and, in places, precipitous slopes, summit surfaces of the high foothills, such as Independent Ridge, Horn Mountain, and Macomb Plateau, are nearly flat or gently rolling (pl. 1).

The major streams are glacier fed-notably the Johnson River, whose source is a compound valley glacier nearly 20 miles long. The 
Johnson River is braided and has a wide, bare flood plain on which shifting channels flow during the warm season. It is navigable with difficulty by river boat in its lower course and is generally unfordable. Although no runoff data are available, the regime of the Johnson River probably parallels that of the Tanana River by having very little runoff in late winter and a maximum of runoff in .July or August. Overflow icings are widespread on the lower part of the flood plain and may persist as late as early July. Much smaller streams are the glacier-fed Berry and Bear Creeks, which have a more regular flow and carry a lower percentage of silt than the Johnson River. Other minor streams are similar to the small streams of the Yukon-Tanana Upland because they drain muskeg-filled valleys and have low discharge and high organic content.

Most of the lakes in the mountains are small and lie in kettle depressions on moraines. Fish Lake and two unnamed lakes in the Mount Hayes C-1 quadrangle are suitable for floatplane or skiplane operations. Shorelines are commonly marshy or boggy. Most of the small ponds do not have through-going drainage, and their water level fluctuates as a result of evaporation and precipitation. Depths are probably 6 to 25 feet, and ice thickness in winter is probably about 3 feet.

\section{CLIMATE}

The climate of the Johnson River area is typical of interior Alaska; the regime is essentially continental but is modified by maritime and topographic factors. A summary of the nearest stations (Big Delta (Fort Greely), which is about 45 air miles to the northwest, and Northway, which is about 95 air miles to the southeast) presents a general idea of the temperature and precipitation means (table 1).

Winters in this part of the Tanana Lowland are cold and usually last from October to April. Minimum temperatures, between $-40^{\circ}$ and $-64^{\circ} \mathrm{F}$, may be expected each winter, but short periods of above freezing temperatures and warm winds may also occur in midwinter. Winter snowfall is light and the snow density is low; little more than 3 inches of moisture falls as snow in the lowland areas. The ground is normally covered with snow to a depth of more than 1 foot.

Seasonal change at breakup in May is rapid. Summer, June through August, is pleasantly warm. Maximum temperatures between $80^{\circ}$ and $90^{\circ} \mathrm{F}$ are common. Mean rainfall is probably about 8 to 12 inches but increases with altitude and varies considerably from year to year. Summer rain, frequently as orographic showers and occasionally as thundershowers, may be heavy at times. The onset of winter is rapid, and leaves fall quickly, but the freezing of the ground and of water 
TABLE 1.-Climatic summary of nearby stations

[Data from U.S. Weather Bureau $(1958,1959)$. Period of record, 15 years. Tr, trace]

\begin{tabular}{|c|c|c|c|c|c|c|}
\hline & \multirow{2}{*}{\multicolumn{2}{|c|}{ Mean temperature $\left({ }^{\circ} \mathrm{F}\right)$}} & \multicolumn{4}{|c|}{ Mean precipitation (inches) } \\
\hline & & & \multicolumn{2}{|c|}{ Total moisture } & \multicolumn{2}{|c|}{ Snowfall } \\
\hline & Big Delta & Northway & Big Delta & Northway & Big Delta & Northway \\
\hline January _. & -5.6 & -17.1 & 0.32 & 0.61 & 7.1 & 8.7 \\
\hline February & 2.9 & -9.4 & .16 & .34 & 2.6 & 4.1 \\
\hline March_. & 12.0 & 6.9 & 34 & 22 & 5.8 & 3. 1 \\
\hline April & 28.4 & 25.8 & 28 & .35 & 2.9 & 2.9 \\
\hline May_. & 46.4 & 44.8 & 64 & 72 & 0.3 & 0.4 \\
\hline June. & 56.4 & 55.7 & 2.31 & 2.00 & $\operatorname{Tr}$ & $\operatorname{Tr}$ \\
\hline July - & 59.5 & 59.2 & 2.99 & 2.89 & 0 & $\operatorname{Tr}$ \\
\hline August_. & 54.1 & 53.7 & 1. 98 & 1.81 & $\operatorname{Tr}$ & 0.3 \\
\hline September.... & 44.1 & 42.5 & 1.43 & 1.18 & 0.6 & 1.5 \\
\hline October $\ldots$ & 27.3 & 24.3 & .50 & .49 & 6.7 & 5.3 \\
\hline November & 7.6 & -2.2 & .29 & .36 & 5.0 & 5.4 \\
\hline December & -2.3 & -14.8 & .33 & .37 & 4.2 & 5.5 \\
\hline Annual & 27.6 & 22.4 & 11.63 & 11. 34 & 35.2 & 37.2 \\
\hline
\end{tabular}

bodies may take a long time. The winter snow cover may be established any time from September to December.

The strongest winds blow down the valleys primarily from the southeast and at times from the south. Although the southeasterly winds are probably the stronger and more frequent, especially in winter, the southerly winds are more important geologically. Flow of air over the range results in strong winds through the deep canyons; these winds move silt and sand on the bare flood plains in summer and, being adiabatically warmed, quickly melt snow in winter.

\section{VEGETATION}

The vegetation of the Johnson River area consists of about equal parts of boreal forest and treeless areas; the latter includes bogs, marshes, flood plains, tundra, and rock deserts. The following summary is based on an unpublished manuscript by L. A. Spetzman, who studied the area in 1957, and on the work of Benninghoff (Holmes and Benninghoff, 1957), who accompanied the senior author in adjacent areas in 1955 and 1956.

Most of the boreal forest is composed of various mixtures of white spruce (Picea glauca), black spruce (P. mariana), white birch (Betula resinifera), and aspen (Populus tremuloides). This mixed forest is typically 20 to 50 feet high and grows on poorly to well-drained soils on the rolling hills of the Yukon-Tanana Upland, the foothills of the Alaska Range, and the moraines and terraces of the Tanana Lowland. A small part of the boreal forest consists of nearly pure stands of white spruce, 40 to 100 feet high, that grow on well-drained low ter- 
races or on gently sloping moraines and bedrock hills near the major rivers. A few balsam poplars (Populus taca-mahacca) occur with the white spruce, usually on the lowest terraces. Scattered patches of low brush and dwarfed trees, mostly less than 20 feet high, occur within the boreal forest. These include recently burned areas where willow of several species, alder (Almus crispa, A. incana) aspen, poplar, and white birch have become established. Low brush and dwarfed trees are also found in muskeg environments, on poorly drained soil in abandoned channels, in kettles, in minor valleys, and on some piedmont slopes. The vegetation includes scattered dwarf birch (Betula nana, $B$. glandulosa), dwarfed black spruce, willow, several varieties of heath plants, and, very rarely, larch (Larix Taricina). A spongy ground cover of mosses and sedges grows beneath the dwarfed trees and brush.

Treeless areas in the boreal forest include bogs, marshes, and flood plains. Bog vegetation consists mainly of sedges, mosses, heath plants, and dwarf willows. Marshes, usually bordering ponds and small streams, support a growth of rushes, sedges, reedgrass, cottongrass, horsetails, iris, poison-hemlock, and waterlilies. Flood plains, subjected to strong winds and shifting sands in summer, and covered in places by overflow icings in winter, are barren or support only scattered willow or soapberry brush.

Extensive thickets of very dense brush grow in the transition zone between the boreal forest and the upland tundra, generally 2,500 to 3,500 feet above sea level. The brush includes willows, alders, dwarf birch, heath shrubs, and dwarf black and white spruce.

Most of the area between tree line and about 5,000 feet, such as Macomb Plateau, Independent Ridge, or Horn Mountain (pl. 1), are covered by alpine tundra meadows. The plants include mosses, lichens, sedges, dwarf birch, willow, blueberry, mountain cranberry, Labradortea, mountain heather, and Lapland rhododendron. On very steep slopes above 3,500 feet and elsewhere above about 5,000 feet, vegetation is absent or consists of rock-desert flora. The latter includes lichens and mosses in isolated mats or cushions, sedges and grasses in tufts, forbs in rosettes or cushions, and low creeping or matted shrubs.

\section{PERMAFROST}

Perennially frozen ground, or permafrost, is widespread but discontinuous in interior Alaska (Hopkins and others, 1955). Permafrost in the Johnson River area is shallow, generally below 3 to 4 feet, in fine alluvium, colluvium, flood-plain deposits, silt and peat deposits, and loess. Its presence can be determined by probing or digging and is commonly suggested by hummocks, tussocks, bog and muskeg vegetation, or dwarfed and deformed trees. Ice in these fine deposits occurs 
as small, disseminated grains; only rarely are large segregations or lenses exposed, and those exposures are primarily in recently excavated banks of the Tanana River. Ice lenses are probably present in pingos. The sites most favorable for near-surface permafrost are bogs and muskegs on kettles, abandoned channels, low flood plains and terraces, the piedmont and minor valleys of the Alaska Range foothills, poorly drained uplands of the foothills, and northward-facing slopes or the floors of minor valleys in the Tanana-Yukon Upland.

Data on the occurrence of permafrost in other geologic units are generally lacking, but some inferences can be drawn by using data from the Big Delta and Fort Greely areas (Péwé, 1953; Holmes and Benninghoff, 1957, p. 164-171). The depth to permafrost in moraine deposits probably varies according to grain size, exposure, drainage, and silt mantle; it also varies widely in gravel deposits in which it may be shallow, as for example along the piedmont where gravel is covered by silt and is abundantly supplied with surface water. As suggested by a few well records, permafrost may be deep or absent in well-drained gravel and sand. Permafrost probably occurs in bedrock of the mountains and hills, but ice content is low and its presence is of little practical significance.

\section{SETTLEMENTS AND TRANSPORTATION}

The only settlement is at Dot Lake, a native village having a permanent population estimated at less than 50 persons. A few other people live on widely scattered homesteads along or near the Alaska Highway and, seasonally, in fishing and hunting cabins on the Tanana River or on a few of the larger lakes. Several sawmills in or near stands of white spruce are in the lower Gerstle River area. The only other developments of significance are a granite quarry near the Gerstle River, a highway maintenance camp on the Johnson River, and a telephone repeater station and microwave communication tower in the Dot Lake area.

The main road is the Alaska Highway, a medium-duty, hardsurfaced road. Short roads lead from the highway in the lower Gerstle River area and near Dot Lake. A short gravel airstrip at Dot Lake is used by light aircraft. The Tanana River is navigable by motorboats and in the past was used by river steamers.

\section{BEDROCK GEOLOGY}

\section{GENERAL FEATURES}

The Johnson River area is underlain by metamorphic rocks which were invaded by granitic rocks. This complex is part of an extensive terrain that underlies much of the Yukon-Tanana Upland and large 
parts of the north side of the Alaska Range (pl. 1). The metamorphic rocks have generally been included in or correlated with the Birch Creek Schist (Moffit, 1954, p. 94; Mertie, 1937, p. 47), a group of rocks of unknown age, but possibly early Paleozoic or Precambrian. The granitic rocks are representative of intrusive rocks of Cretaceous age now extensively exposed in the Yukon-Tanana Upland and Alaska Range.

Dikes ranging in composition from ultramafic to granitic cut the metamorphic rocks. They are of several ages; the metamorphosed dikes were emplaced before the metamorphism of the Birch Creek Schist, but most are unmetamorphosed and younger. The granitic rocks are also cut by dikes, which are mostly dacitic or rhyolitic; some are andesitic, basaltic, or ultramafic.

Areas underlain by metamorphic rocks are not topographically distinct from those underlain by granitic rocks. It is generally impossible to distinguish the two types of rocks or contacts between them from the air or by means of aerial photographs. The number of outcrops is limited by an extensive cover of glacial deposits, alluvium (pl. 1), rubble, and vegetation.

\section{METAMORPHIC ROCKS}

\section{OCCURRENCE AND DESCRIPTION}

Gneiss and schist, mainly formed from sedimentary rocks, are the most abundant metamorphic rocks in the Johnson River area, but some quartzite, hornfels, amphibolite, and augen gneiss are also found. Gneiss and schist compose most of Independent Ridge, and other outcrops are scattered throughout the mapped area. Massive quartzite forms vertical cliffs more than 50 feet high on the northwest side of Bear Creek about 3.5 miles southeast of Fish Lake, and smaller outcrops occur in a fault block at the south end of Independent Ridge and at a few other localities. Amphibolite crops out along Bear Creek near its contact with granodiorite, and hornfels occurs on the west side of the Macomb Plateau near the igneous contact. Augen gneiss was only found on the east side of Chief Creek, 3 miles southwest of the Chief Creek Bridge on the Alaska Highway.

The schist is gray or tan and ranges from finely crystalline, as found in some mica schist, to coarsely crystalline, as found mostly in quartz schist. Some mica schist has garnet porphyroblasts as large as one-third of an inch in diameter. The schist is predominately composed of quartz and muscovite, and a wide variation exists in the relative proportions of these two from place to place.

Tremolite also occurs in some schist. A tremolite-bearing garnetmuscovite schist on Independent Ridge contains plagioclase, quartz, 
colorless amphibole, chlorite, rutile, and apatite as minor constituents.

The gneiss is predominantly gray but in some cases is tan and has a slightly orange or pink cast, especially on weathered surfaces. It ranges from finely to coarsely banded; some gneiss is spotted, having only indistinct banding due to alined or subparallel segregations of dark minerals. The most abundant minerals composing both the banded and spotted gneiss are quartz, usually strained, but in some specimens, fractured; oligoclase or andesine; potassium feldspar, generally perthitic; biotite, muscovite; garnet; and, in some gneiss, clinozoisite, hornblende, and epidote. Quartz composes more than 50 percent of most gneiss; few gneisses are rich in feldspars. The grain size diameter of quartz, biotite, and feldspar commonly averages between 1 and 2 millimeters. The chemical composition of a typical well-foliated garnet-bearing quartz-mica gneiss is given in table 2.

Augen gneiss, similar to that described by Mertie (1937, p. 202) in the Yukon-Tanana Upland is gray or tan on fresh surfaces but weathers to a reddish tan. It contains deformed feldspar augen as much as 3 inches long. Quartz and biotite are the other principal mineral constituents.

White, dense, milky quartz veins and lenses are abundant throughout the metamorphic rocks. Some veins are parallel in foliation, but others crosscut it and fill old fractures.

White or tan quartzite beds that are as much as 20 inches thick occur interbedded with schist and as large thick-bedded masses. The quartz-

TABLE 2.-Chemical analyses of rocks from the Johnson River area, Alaska

[Sample numbers appear on pl. 1. Routine rapid rock analyses by Paul Elmore, Ivan Barlow, Samuel Botts, and Gillison Chloe, U.S. Geol. Survey, Mar. 20, 1961]

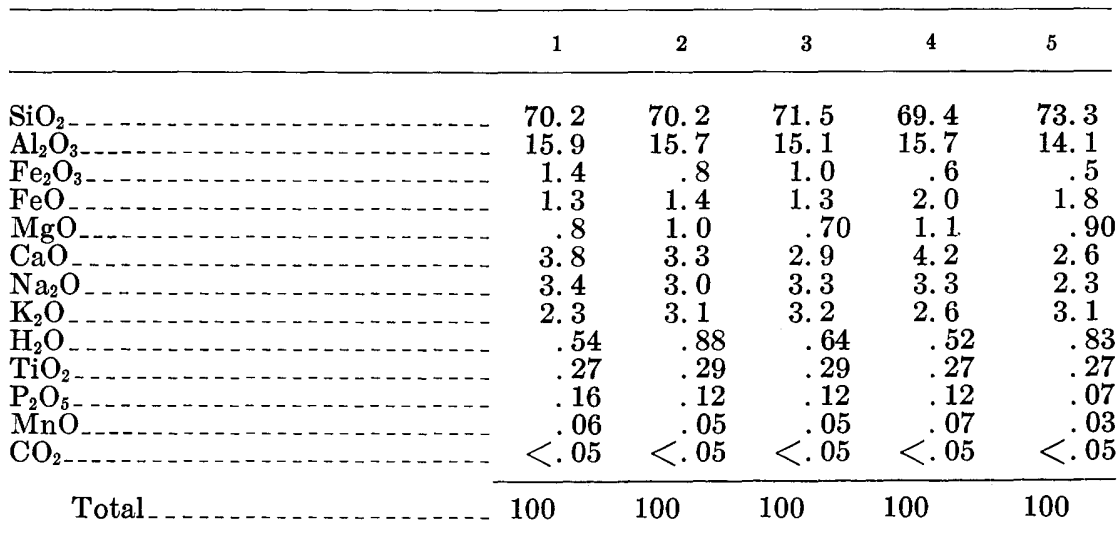

1. Granodiorite from $1 \frac{1}{4}$ miles east of Berry Creek in cut for pipeline on north side of Alaska Highway.

2. Granodiorite from half a mile northwest of Dot Lake on west side of Alaska Highway.

3. Granodiorite from cut in road to microwave communication station about 0.8 mile south of Dot Lake

4. Granodiorite from quarry on north side of Alaska Highway 0.7 mile east of the Gerstle River.

5. Garnet-mica gneiss from the north side of Tanana River half a mile east of the mouth of the Johnson River. 
ite contains variable amounts of sericite, biotite, and plagioclase as impurities.

Schistose amphibolite is interbedded with schist and gneiss in a few places. It is composed of green hornblende, plagioclase, quartz, and biotite. Amphibolite lacking well-developed foliation but having crystalloblastic texture also occurs. It is composed of hornblende, plagioclase, and quartz.

Hornfels is rare, but that from the west side of the Macomb Plateau primarily consisted of quartz, plagioclase, perthitic potassium feldspar, garnet, biotite, and partly altered amphibole.

\section{MINOR STRUCTURES AND METAMORPHIC GRADE}

The metamorphic rocks in the Johnson River area form a complex of unknown thickness and structure. Nearly all the rocks are foliated, largely owing to preferred orientation of constituent minerals. Distinctive beds that could be traced from place to place were not found. In most places indications of original bedding have been obliterated. However, on Independent Ridge, quartzite beds, which are 20 inches thick and interlayered with pelitic schists, suggest that here foliation is parallel to the original bedding, but even these beds cannot be traced to adjacent outcrops.

The attitude of the foliation ranges from nearly horizontal to vertical; southerly dips are most common. Dominant strike directions are not clearly evident from the limited data, except on the north end of Independent Ridge where a strike trending west-northwest is dominant. Planes of foliation are usually wavy or crenulated; lineations, mostly due to parallel alinement of the axes of microfolds, strike and dip in directions different from the foliation but were evident in only a few outcrops and could not be related to larger structures.

The metamorphic rocks of the Johnson River area are the product of regional metamorphism of dominantly pelitic and psammitic sedimentary rocks and are mostly of the amphibolite facies. They are probably polymetamorphic (D. M. Ragan, oral commun. 1964), although the number and time of the metamorphic events have not been determined. Contact metamorphic effects were recognized in only a few places, such as near the margin of the granitic intrusive on the Macomb Plateau where hornfels was found. Also, in some gneiss that borders the intrusive, garnet has altered to chlorite. Evidence of possible retrograde metamorphism was observed in a few thin sections of metamorphic rocks not known to be near the margin of granitic intrusives. A garnet-mica schist on the north side of the Tanana River has plagioclase partly replaced by clinozoisite, late muscovite shear zones, and exsolution textures in plagioclase. 


\section{AGE}

The age of the metamorphic rocks of the Johnson River area is not known. Mertie (1937, p. 56) accepted an early Precambrian age for the Birch Creek Schist in the Yukon-Tanana Upland largely on the basis of its supposed relationship to the Tindir Group, which is also Precambrian but younger than the Birch Creek Schist. Now the Tindir Group is believed to be separated from the Birch Creek Schist by a major fault; consequently this relationship cannot be used for dating.

Isotopic methods of dating have been applied to the Birch Creek Schist in several places in the Yukon-Tanana Upland but have not yet given any proof that the schist is Precambrian in age. So far, the age measurements only indicate that local metamorphism of the Birch Creek Schist in the Yukon-Tanana Upland took place in conjunction with Mesozoic plutonic activity (Wasserburg and others, 1963). In the Johnson River area, the primary plutonic activity was probably in Cretaceous time, the period indicated by lead-alpha age determinations on zircon from the intrusions. (See p. 21.)

\section{IGNEOUS ROCKS}

\section{GRANITIC ROCKS}

\section{DISTRIBUTION AND DESCRIPTION}

Granitic rocks, part of a large pluton, crop out in an extensive area between Chief Creek and the Johnson River and north of the Tanana River (pl. 1). They are dominantly granodiorite, but granite, quartz monzonite, quartz diorite, and diorite also occur.

The granodiorite forms conspicuous tors on Horn Mountain and on Knob Ridge and crops out in nearly vertical bluffs along the Tanana River Prospect Creek cuts through granodiorite and has formed a narrow $V$-shaped valley having granodiorite walls 800 feet high. The granodiorite is generally light gray when fresh because of an abundance of light-gray and white feldspar phenocrysts, but upon weathering it commonly acquires a pink cast. In some places the fresh rock is also pink because it contains pink feldspar crystals. The granodiorite is commonly porphyritic, but fine- to coarse-grained equigranular types also occur. Dark-gray xenoliths, 1 inch to more than 2 feet in diameter, are abundant in many places; light-tan quartzite fragments as much as 2 feet in diameter were found in granodiorite tors on Knob Ridge.

The granodiorite consists primarily of plagioclase, potassium feldspar, quartz, biotite, and hornblende. Accessory minerals include epidote, magnetite, orthite, apatite, zircon, sphene, sericite, chlorites, and rarely monazite. The plagioclase, generally andesine, occurs as sub- 
hedral to euhedral crystals as much as 2 inches long. Oscillatory zoning is characteristic, and the cores of crystals are more calcic than the rims. Potassium feldspar crystals are mostly anhedral and commonly poikilitic having inclusions of mafic minerals, plagioclase, and apatite. Microcline is common, and much of the potassium feldspar is perthitic. Some feldspar has altered to sericite.

Quartz is anhedral and commonly shows strain shadows. Biotite is subhedral to euhedral and commonly poikilitic, containing inclusions of feldspar, magnetite, apatite, and zircon having pleochroic halos. Biotite, or biotite and green hornblende, may be present. The hornblende may have inclusions of apatite and magnetite. An amphibole displaying a very low birefringence, small extinction angle, and small optic angle occurs in many specimens. Minerals of the chlorite group, commonly having anomalous interference colors, have formed from the alteration of biotite and homblende. Euhedral crystals of magnetite as much as 0.1 inch across are fairly common.

Diorite forms a small but conspicuous knob on the ridge northeast of Fish Lake and occurs in some places along the margins of the intrusions, for example, between Sand and Billy Creeks on the north side of the Tanana River. The diorite is mostly dark gray and noticeably darker in color than the granodiorite. It is fine to medium grained and equigranular. It is principally composed of feldspar, hornblende, biotite, and quartz. Accessory minerals are apatite, sphene, magnetite, sericite, chlorites, muscovite, allanite, epidote, and zircon. Most of the plagioclase is strongly zoned, and some plagioclase crystals invade hornblende crystals. The potassium feldspar is commonly microcline, but in many specimens it is perthite. Poikilitic textures occur in some. Biotite is the most common mafic mineral, but hornblende may also be present; in one specimen biotite and hornblende were intergrown. Zoned allanite crystals occur in some diorites. The mafic minerals are considerably altered in many specimens, and in general, the alteration is greater in the diorites than in the granodiorites. Routine rapid rock analyses of four representative granitic rocks from different localities in the Johnson River area are given in table 2.

The textural and compositional differences in the pluton have not been mapped; therefore, no significant distribution pattern has been recognized. In general, porphyritic rocks having exceptionally large phenocrysts-1 to 2 inches long-occur on the Macomb Plateau. Medium-grained equigranular rocks are characteristic in the area around Dot Lake and to the south of it. Porphyritic rocks having phenocrysts as much as 1 inch long are common on Knob Ridge, in the hills east of the Gerstle River south of Pegmatite Creek, and in much of the area north of the Tanana River. 
In most places preferred orientation has not been detected in the minerals of the pluton, but locally on the Macomb Plateau a weak foliation due to the crude alinement of large feldspar crystals was recognized.

Sheeting of unknown origin is locally conspicuous. The sheeting planes are 2 to 15 feet apart and may be horizontal or have a slight dip. On the ridge east of Berry Creek where the sheeting planes have a slight dip, erosion has produced topographic forms similar to cuestas.

The granitic rocks are commonly broken by two or more sets of joints. The joints are 3 to 15 feet apart, and the joint planes dip $65^{\circ}$ to $90^{\circ}$. Along faults or near contacts with the metamorphic rocks where severe shattering has occurred, fractures are very closely spaced, like those found in the exposures along the north side of Prospect Creek (fig. 4). The granodiorite at Gerstle River quarry (fig. 5) has typical rectangular jointing. One set of joints strikes N. $30^{\circ} \mathrm{E}$. and $\operatorname{dips} 80^{\circ} \mathrm{N}$., and the other strikes N. $5^{\circ} \mathrm{W}$. and dips $75^{\circ} \mathrm{E}$. A set of vertical joints along the crest of unglaciated Knob Ridge strike northward, roughly parallel the ridge, and are the controlling structures in the prominent tors which give the ridge its name (fig. 6). A second set of joints strikes eastward and dips $70^{\circ} \mathrm{S}$. Single monolithic granitic

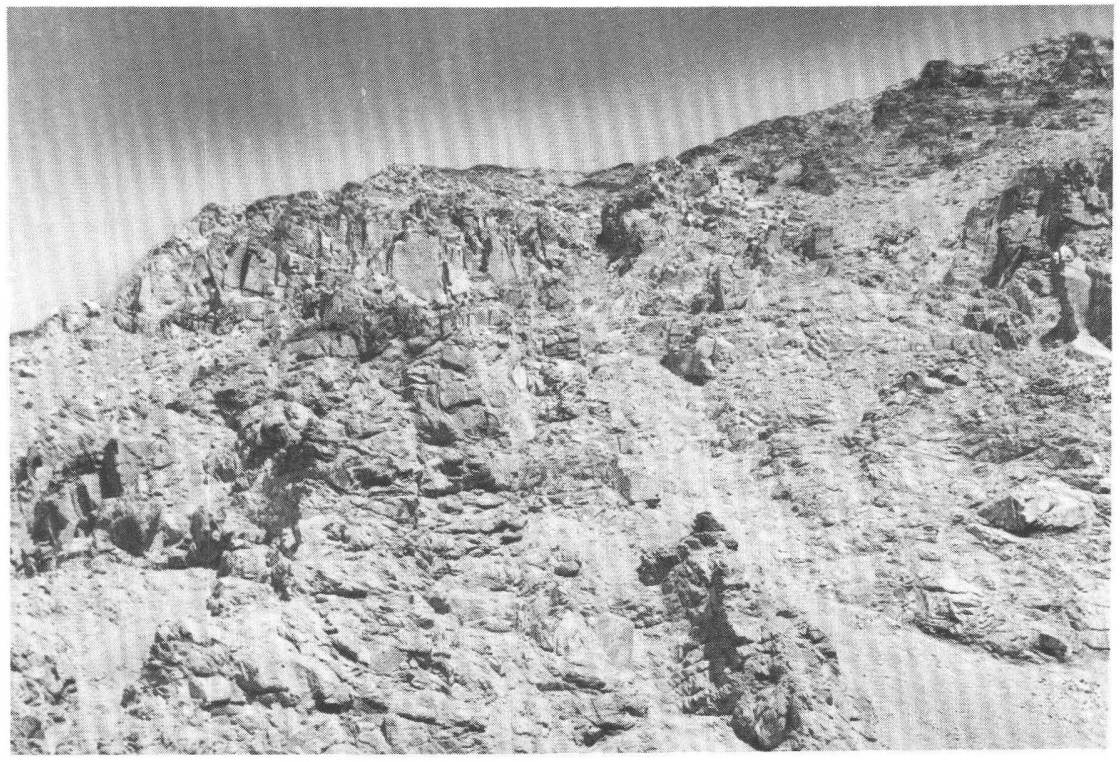

FIGURE 4. Shattering in granodiorite. The granodiorite on the north side of Prospect Creek is severely shattered; frost action is gradually breaking up the rock along the many fractures. View to the north. Photographed in July 1960. 


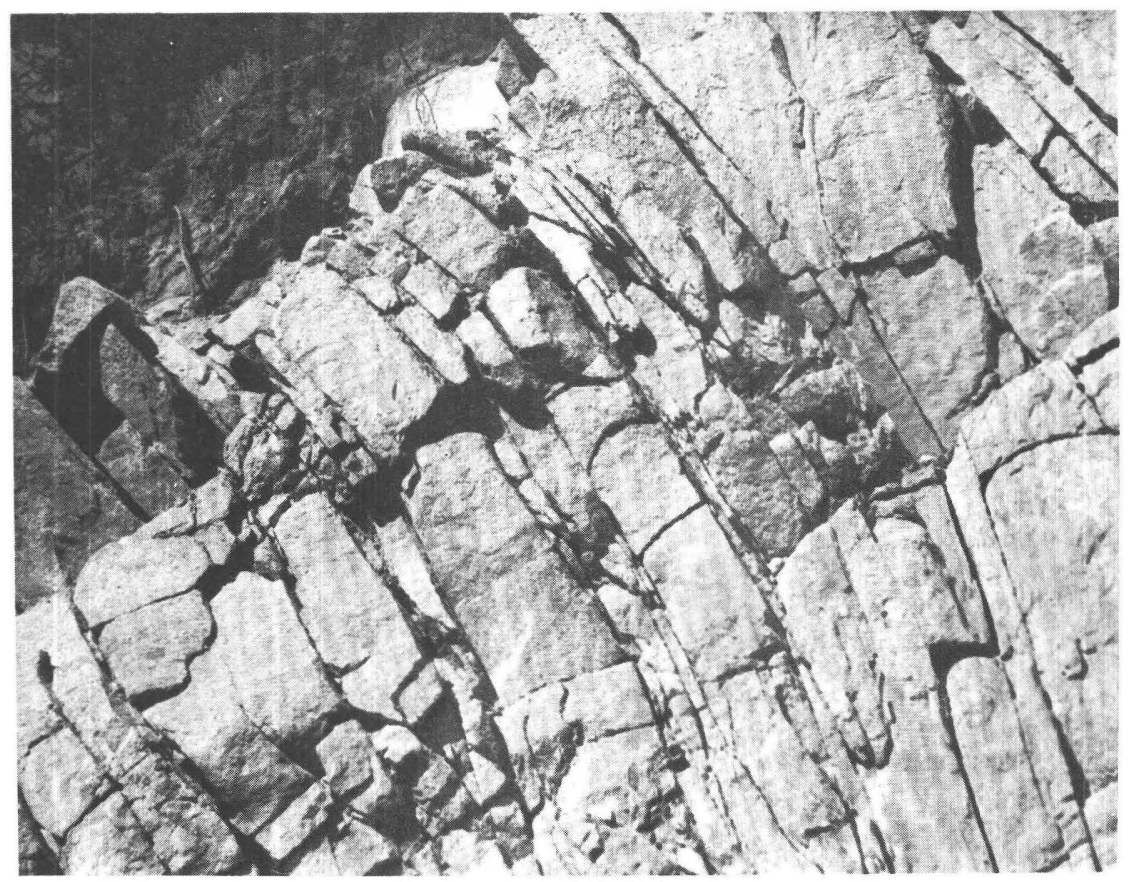

FIGURE 5. Jointing in granodiorite. Rectangular jointing is well displayed in the quarry on the north side of the Alaska Highway 0.7 mile east of the Gerstle River. The prominent set of joints in the picture strikes $\mathbf{N}$. $5^{\circ} \mathrm{W}$. and dips $75^{\circ}$ E. Nearly horizontal sheeting can also be seen. Blocks of granodiorite in the upper part of the exposure are tilted because of mass movement. Photographed in August 1960.

blocks or groups of blocks broken by widely spaced joints stand as prominent features on other upland surfaces, such as Horn Mountain, but in many places such erosional remnants were removed by glaciation.

\section{GENETIC RELATIONSHIPS}

The mineralogy, chemical composition, and distribution of the granitic rocks of the Johnson River area suggest that they are all genetically related and probably part of a single intrusion. The variations in texture and composition are those that might be expected from differentiation and from assimilation of intruded rocks during the emplacement of such a pluton.

The rocks of the Granite Mountains, 15 miles northwest of Independent Ridge and in the Mount Hayes D-3 quadrangle, may also be a part of this pluton. Robert Forbes (written commun., 1960) studied four specimens from the Granite Mountains and noted that the amphibole in them has a very low birefringence (about 0.15), a small 


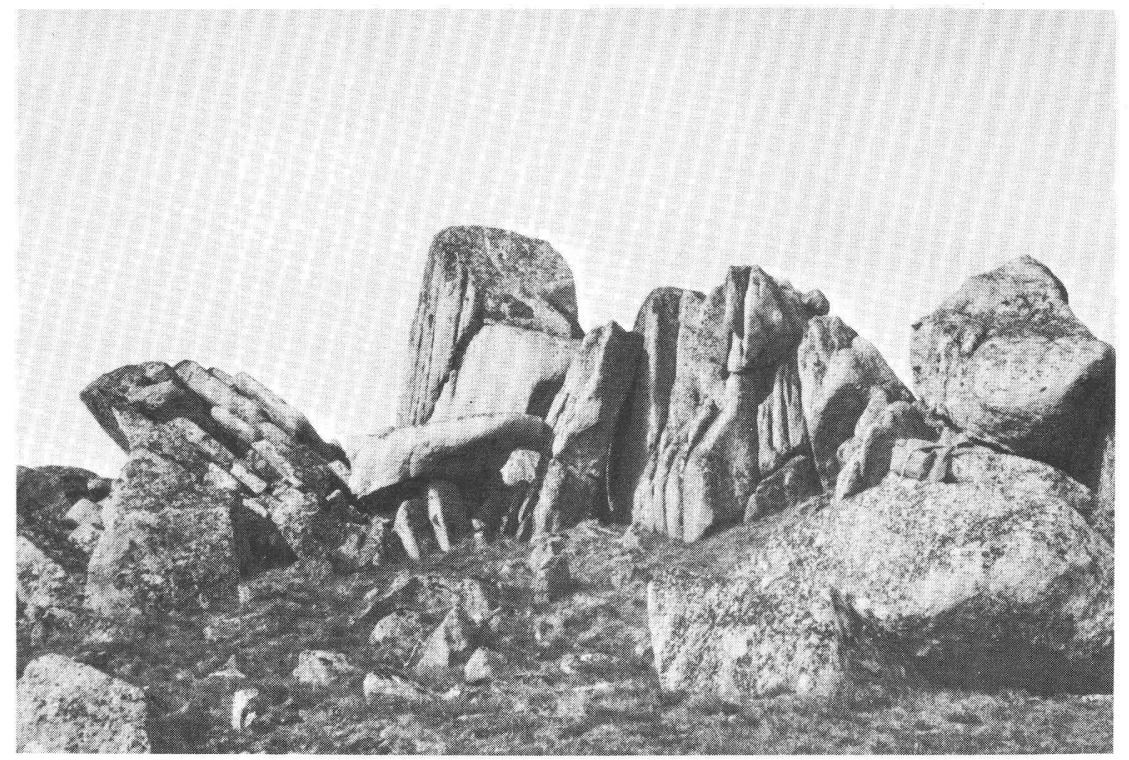

Figure 6. Horn Mountain, the highest point on the Macomb Plateau, is composed of groups of weathered joint blocks of porphyritic granodiorite. The joints are vertical. Photographed in August 1961.

extinction angle $\left(Z\right.$ to $\left.c 10^{\circ}\right)$, and small optic angle (negative, $2 \mathrm{~V}$ about $30^{\circ}$ to $40^{\circ}$ ). Pleochroism is: $\mathbf{X}$, light greenish tan; $\mathbf{Y}$, olive; and $Z$, emerald green. Amphibole having similar characteristics was noted in specimens from the Johnson River area. Forbes (oral commun., 1961) also noted that other mineralogical, textural, and chemical similarities exist between rocks of the Johnson River area and those of the Granite Mountains.

\section{CONTACTS}

Contacts observed between the granitic and metamorphic rocks are of three types: zones of contact breccia, crosscutting instrusive contacts, and zones of mixed granitic and metamorphic rocks.

A zone of contact breccia 600 feet or more wide is exposed along Prospect Creek. The breccia consists of angular, randomly oriented fragments of gneiss and schist in a granitic matrix. The fragments, which range from less than an inch to more than 15 feet across, are believed to have come from adjacent metamorphic rocks. Only a few of them show alteration megascopically that can be attributed to effects of the invading granite. A second type of contact breccia was found on the west side of Independent Ridge. Here the contact zone is 20 to 100 feet wide, pink biotite-hornblende granite being separated 
from biotite-quartz schist by white mylonite or a breccia of white quartzite in a granitic matrix.

In most contacts the granodiorite cuts across the foliation of the metamorphic rocks without visible evidence of physical or chemical disturbance of the rock, except that, in places, the metamorphic rocks are somewhat more fractured than those at a distance from the contact. Contact zones where igneous and metamorphic rocks are complexly mixed occur on the north side of the Tanana River and west of Fish Lake. The zones are as much as 0.5 mile across.

\section{AGE}

The granitic rocks of the Johnson River area were presumed to be of Mesozoic age by Moffit (1937, p. 215) because of their similarity to other granitic rocks of Mesozoic age in the Alaska Range. Leadalpha age determinations on zircon in granodiorite from four different localities in the Johnson River area confirm this by indicating a Cretaceous age. T. W. Stern, U.S. Geological Survey (unpub. data, $1960)$ reported the following lead-alpha ages:

6. Granodiorite from quarry near Gerstle River (sample 4, table 2 for chemical analysis)

7. Granodiorite from Horn Mountain $90 \pm 10$

8. Quartz diorite from bluff along north side of the Tanana River, 7.8 miles upstream from the mouth of Berry Creek $110 \pm 10$

9. Granodiorite from Alaska Highway, three-fourths mile northwest of Dot Lake (near sample 2, table 2)

$110 \pm 10$

The close agreement in lead-alpha ages of granodiorite from several localities separated from one another by metamorphic rocks is further indication that the intrusive rocks are probably part of the same pluton.

\section{DIKES}

Dikes are abundant in the Johnson River area and cut both the metamorphic and granitic rocks. A few mafic dikes in the metamorphic rocks have been metamorphosed along with the strata that they intrude, but most of the dikes are not metamorphosed. Many of the dikes are granitic or aplitic and are probably offshoots of the pluton. Other dikes are rhyolitic to ultramafic, exhibit a variety of textures, and cut the plutonic rocks as well as the metamorphic rocks. Descriptions of several different representative types of dikes follow. Only felsite dikes were mapped and are shown on plate 1.

An ultramafic dike about 4 feet wide cuts porphyritic granodiorite along Prospect Creek. The contact between the dike and granodiorite is sharp. The dike is fine grained along its margins but more coarsely 
crystalline in the interior. It consists of biotite, clinopyroxene, and carbonate minerals. This dike and other mafic or ultramafic dikes exposed along Prospect Creek are offset by numerous small faults having displacements of 1 to 5 feet. In the Johnson River area, ultramafic dikes were only found in the Alaska Range in the southernmost part of the mapped area.

A fine-grained basaltic dike that strikes east cuts porphyritic granodiorite near the summit of a hill on the north side of the Tanana River about 4 miles northwest of the month of the Johnson River. Small aplitic dikes also cut the granodiorite in the same locality. Finegrained basaltic dikes seem to be somewhat more abundant north of the Tanana River than south of it.

Two dikes of fine-grained, equigranular quartz monzonite cut porphyritic granodiorite on the northwest side of the tributary valley that joins the Johnson River at the south end of Independent Ridge. The dikes, one 20 feet wide and the other 50 feet wide, do not have chill zones, and their contacts with the granodiorite are sharp. Small aplitic dikes and stringers also occur at this locality, as they do throughout the granodiorite of the pluton.

In the roadcut 1 mile northwest of Dot Lake a greenish-gray porphyritic felsite dike, altered and much weathered, cuts the granodiorite. The dike strikes about N. $40^{\circ}$ E. and dips $55^{\circ}$ W. Similar dikes of various widths are numerous in this vicinity.

Light-gray, cream-colored, and light-pink rhyolitic(?) dikes are abundant in the area south of Dot Lake. They contain well-terminated quartz phenocrysts in a fine-grained groundmass. The dike rock is shattered, and fragments one to a few inches across show distinct conchoidal fracture.

\section{STRUCTURAL RELATIONSHIPS AND FAULTS}

The Johnson River area includes that part of the Alaska Range that is north of the great arcuate Denali fault. In the Johnson River area, the highly deformed and structurally complex metamorphic rocks that compose this northern block of the Alaska Range appear to be continuous with the rocks in the adjacent Yukon-Tanana Upland (pl. 1). Although metamorphic rocks, similarly deformed, compose the exposed basement throughout most of the Yukon-Tanana Upland, other parts of interior Alaska and the Yukon Territory, Canada, details of their structure remain unknown in most areas.

Geomorphic features, such as the high, steep, north front of the Alaska Range, triangular facets, and the Tanana Valley, are suggestive of a system of faults along the north front of the Alaska Range in the Johnson River area. Highly sheared and crushed zones occur 
in the granitic rocks exposed in the Tanana Valley, but distinct offsets and significant differences in lithology on the two sides of the valley have not been recognized.

Two high-angle faults have been mapped (pl. 1) at the south end of Independent Ridge, and in the stream valley southwest of the south tip of the ridge several zones of crushing occur.

A fault in granodiorite, striking about N. $80^{\circ}$ E. and dipping steeply westward, is exposed in the roadcut 1 mile northwest of Dot Lake, but it cannot be traced because of vegetational cover. A zone of fine gouge one-fourth to one-half inch thick grades eastward into a 5-foot-wide zone of crushed rock. Mylonite borders the crushed rock on the east. Nearly vertical felsite dikes also cut the granodiorite in the shear zone at this locality.

On the granodiorite ridges south of Dot Lake, small topographic highs that are offset from the connecting parts of the ridge suggest that movement occurred along nearly vertical planes. Associated zones of mylonite were found, but outcrops were poor and the zones could not be traced.

\section{SEDIMENTARY ROCKS}

\section{CARBONACEOUS SILT AND CLAY}

Upper Tertiary sedimentary rocks of silt, clay, and thin carbonaceous layers occur on a tributary of the Johnson River between Horn Mountain and Macomb Plateau (fig. 7). The beds apparently are gently inclined to the north and are at least 150 feet thick. A description of a section in which two carbonaceous layers are exposed follows. This section is considerably thinner than most; the base of all exposures observed is apparently covered.

Section of carbonaceous silt and clay, south side of Horn Mountain, 8 miles east of the Johnson River

Pleistocene :

Thickness

Ground moraine, slumped (feet)

Tertiary:

Carbonaceous silt and clay:

Silt, medium-gray, having yellow mottling

Clay and silt; gray, having yellow mottling and lenses of gray silt.

Shale, carbonaceous (bone coal), black, plastic;

having plant parts__-_-_- .3

Silt, dark-gray _-___- .

Coal, black; having plant parts__-_-_-_-_-_-_-_-_-_-_-_-_-_-_

Silt, gray, arkosic ; slumped in places; to base

Benninghoff (Benninghoff and Holmes, 1961) has described a spore and pollen flora from the carbonaceous layers that includes the coni- 


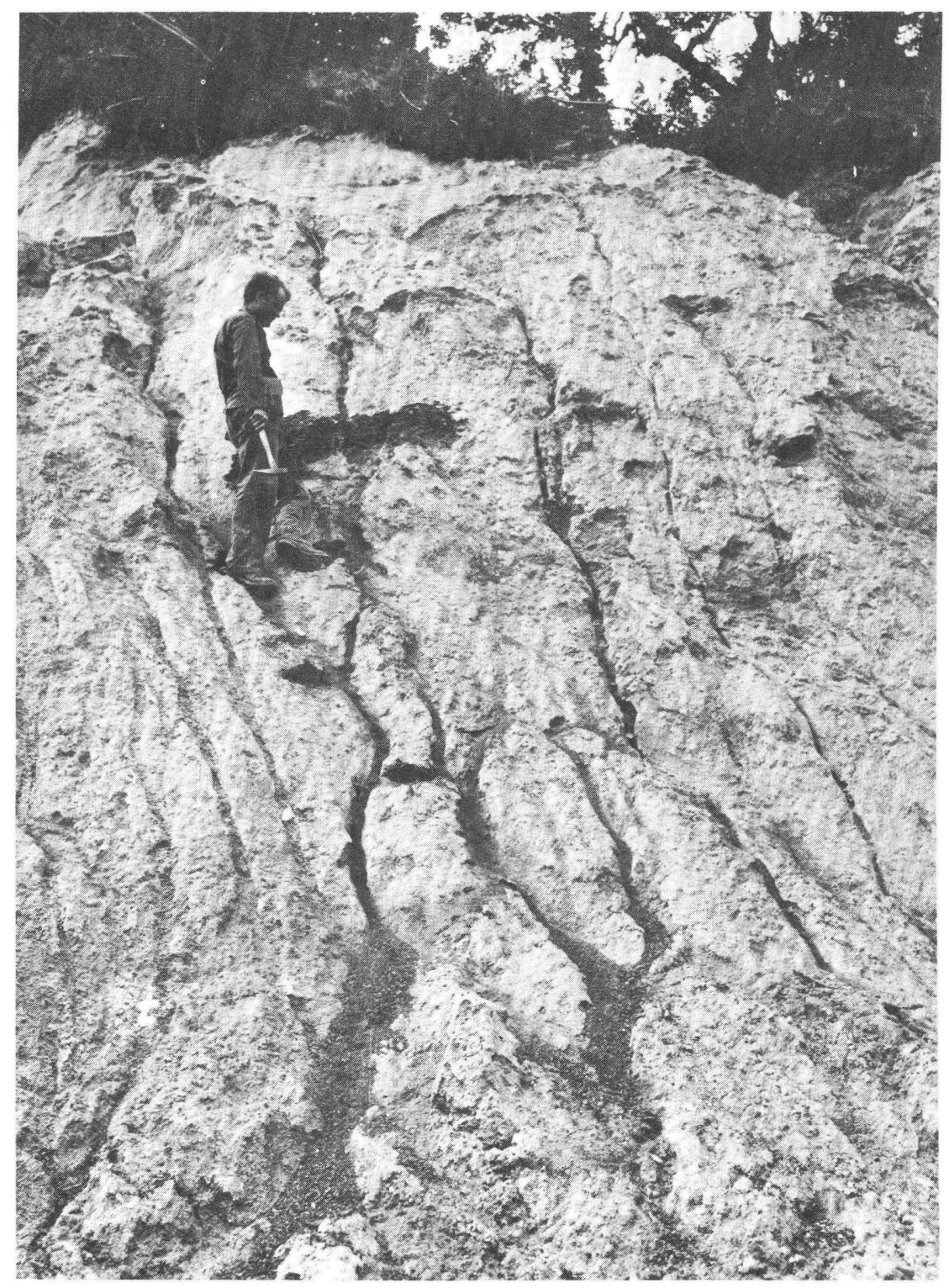

Figure 7. Carbonaceous silt and clay deposits. Massive, poorly bedded, gray arkosic silt and clay with conspicuous layers and lenses of carbonaceous silt and coal. Photographed in July 1960. 
fers Picea, Pinus, and Tsuga (two species); broad-leaved tree genera Betula, Alnus, Carya, Juglans?, Quercus?, and Tilia; Ilex; ferns Dryopteris, Osmunda cinnamomea, and Adiantum; and club moss Lycopodium. Benninghoff (Benninghoff and Holmes, 1961) regarded these beds as possibly Pliocene, because they contain a mixture of conifer and broad-leaved tree pollen and hence differ from the temperate middle Tertiary floras and those of the Pleistocene. However J. A. Wolfe (written commun. 1964), believes the Johnson River beds are no younger than Miocene in age, because the pollen assemblage contains several exotic genera which Wolfe thinks are not of Pliocene age in Alaska. Wolfe (written commun., 1966) further believes that the Johnson River pollen assemblage looks like that from the upper part, but not the uppermost unit, of Wahrhaftig's Nenana River coalbearing formation (Wahrhaftig, 1958, p. 10; MacNeil and others, 1961, p. 1806), which Wolfe regards as Miocene in age.

The lithology and occurrence of these beds indicate that they were deposited in a deep but small basin and that they were mostly derived from local granitic rocks at a time when the foothills of the Alaska Range possessed moderate to high relief.

\section{NENANA GRAVEL}

A small patch of poorly consolidated, deeply weathered, brown, well-rounded gravel, resembling the Nenana Gravel, occurs on the north end of Independent Ridge. It is apparently flat lying, is at least 8 feet thick, rests on a surface approximately 1,600 feet above the Tanana River, and is composed of pebbles, cobbles, and boulders as much as 0.9 foot in diameter. The gravel is composed of quartz, schist, quartzite, diorite, and granite.

Moffit (1954, p. 146-147) describes similar deeply weathered, partly consolidated gravel on the west side of the Gerstle River, and near MacCumber and Morningstar Creeks in the mountains south of Delta Junction, which is outside the mapped area. Poorly to partly consolidated, deeply weathered, and apparently pre-Pleistocene gravel on the north flank of the Alaska Range is generally correlated with the Nenana Gravel. In the Nenana River region, this gravel in places unconformably overlies the Tertiary coal-bearing formation. On the basis of one fossil (Trapa bispinosa), the Nenana Gravel had been tentatively assigned an age of middle Miocene or younger. Pollen floras in the Nenana Gravel resemble pollen floras from nonmarine sediments in the Aldan River valley of northeastern Siberia that were 'thought (MacNeil and others, 1961, p. 1806) to be of late Miocene or early Pliocene age. More recent pollen studies suggest that the Nenana Gravel is younger than the carbonaceous silt and clay deposits and is probably of Pliocene age (J. A. Wolfe, written commun., 1964). 


\section{GLACIAL GEOLOGY}

Pleistocene glaciation in this area consisted of two major episodes that are correlated with the Delta and Donnelly Glaciations of the Delta River district (Péwé, 1952; Holmes, 1959). Minor advances occurred during the waning phases of Donnelly Glaciation and again in the Recent. Glacial ice flowed from scores of cirques in the central part of the Alaska Range-notably from those at the head of the Johnson River glacier (fig. 1). The ice flowed down the main valleys and emerged on the Tanana Lowland as piedmont glaciers. Several other ice masses remained cirque glaciers or valley glaciers. Small icecaps formed on the high rolling foothills and were the sources of one or more outlet glaciers. Existing glaciers in the mapped area are very small compared with the Johnson River glacier to the south (fig. 3), but most have deposited large moraines in the past few thousand years; many of the modern moraines have developed into active rock glaciers.

\section{DEPOSITS OF THE DELTA GLACIATION}

\section{DISTRIBUTION}

End moraines of the Delta Glaciation, the oldest recorded here, are poorly exposed and appear usually as subdued, partly buried moraine remnants. Only a narrow rim of the Delta end moraine is exposed in the Little Gerstle (fig. 8), Berry, or Bear Valleys (pl.1). In the lower Johnson River valley, the Delta end moraine is not exposed. The only well-formed Delta end moraine not overridden by younger glaciers lies on Dry Creek. Small, modified Delta end moraines occur in some of the hanging valleys on the north rim of Horn Mountain.

Ground moraine, on the other hand, is extensive and rests on high bedrock shoulders flanking the Gerstle River valley, on Horn Mountain and Macomb Plateau, and on the uplands extending southeastward from Berry Creek (pl. 1). The distribution of this drift indicates it was deposited by several icecaps on surfaces 3,500 to 5,500 feet above sea level. The large icecap in the Macomb Plateau and Berry Creek areas was fed in part by small cirque glaciers in the high mountains. However, because it was as high as independent cirque glaciers nearby, much of the icecap was probably above firn limit; and it was, therefore, nourished from its own accumulation area.

Movement of the ice, as suggested by the present topography and by the distribution of till, was down Berry and Bear Creeks to the northeast, down Dry Creek to the north, and in a westerly direction toward the upper Johnson River. The Macomb Plateau ice probably merged with a valley glacier in the Johnson River valley to nearly fill this deep trench. Ice on Horn Mountain probably moved radially and pos- 


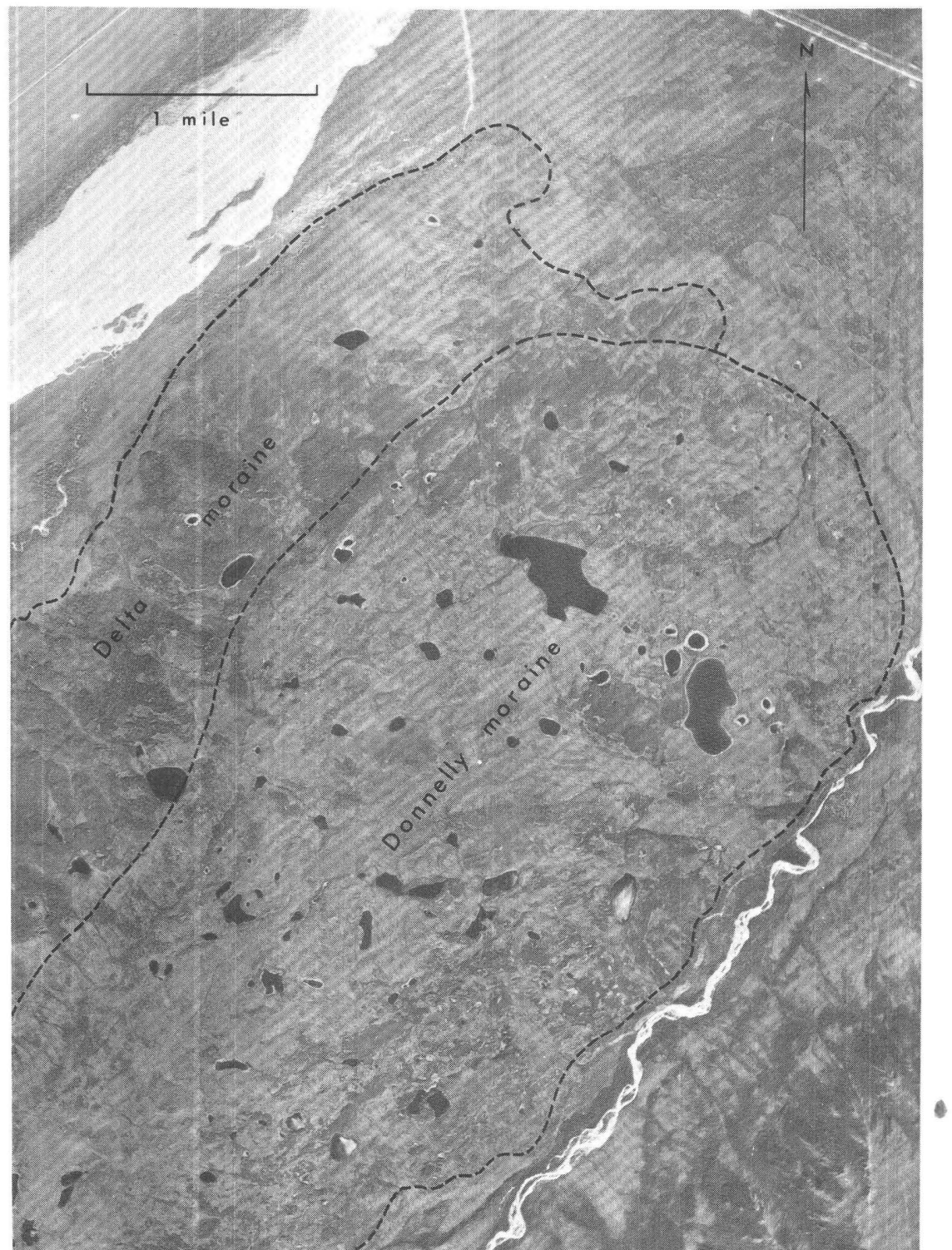

Figure 8. End moraines between the Gerstle and Little Gerstle Rivers. The Delta end moraine, appearing on the west and north, was partly overriden by the Donnelly glacier as it moved northeastward through the Little Gerstle River lowland. The outer edge of the Donnelly moraine is marked by a discontinuous ridge and by a change in the topographic texture. The Delta moraine has fewer undrained depressions, is more subdued, and has been channeled by melt water from the Donnelly glacier. U.S. Geological Survey photograph, 1954. 
sibly merged with the Macomb Plateau ice on the south. Extensive ice sheets covered the high, nearly flat surfaces along the west side of the Little Gerstle depression. Sources of this ice lay in the high terrain southwest of the mapped area (fig. 1). The present topography suggests that ice in the upper Johnson River valley moved northwestward through the low, broad trough connecting the Little Gerstle and Johnson Valleys. Here it merged with ice from the upper Little Gerstle area and deposited an end moraine (fig. 8).

\section{FORM}

Delta moraines retain little of their original character, except for those in the Little Gerstle River and Dry Creek valleys. Elsewhere, kettles, knobs, and ridges have been modified by stream erosion, especially during the younger glaciation, and by mass movement, frost action, sheet wash, and eolian deposition. End moraines of the Delta Glaciation have a maximum thickness of about 200 feet and local relief not exceeding about 100 feet.

Microrelief on end moraines includes well-weathered, scattered, partly buried boulders, tussocks, hummocks, and solifluction lobes. Ground moraine is mostly smooth, as, for example, on Macomb Plateau. Here the terrain is marked only by widely scattered erratic boulders, a few ponds, and frost features. The most obvious are parallel or dendritic patterns ("horsetail drainage" lines). Smaller features include solifluction lobes, nonsegregated circles (tussocks and hummocks), segregated circles (stone polygons) and stripes (stone stripes), and thaw pits.

Delta till has been modified elsewhere by mass movement; the resulting mixed deposits have the characteristic surface features of colluvium or rubble. On Horn Mountain, Delta ground moraine has been mixed with debris from underlying bedrock (pl. 1). In the upper Bear Creek drainage area, Delta till, although not mixed with bedrock, has been deeply disturbed by frost action and mass movement on steep slopes; it is mapped as a subunit-disturbed and modified Delta moraine deposits.

\section{LITHOLOGY}

Moraine deposits of the Delta Glaciation are composed of all locally available rocks in a matrix of light-yellowish sandy silt. As the Delta glaciers were very extensive and spread laterally over the rolling uplands, the source materials were well mixed, so that no obvious differences in the lithology are apparent throughout the area. Iron oxide staining has penetrated to the base of the deepest exposure; on the southwest edge of Horn Mountain, oxidation has reached a depth of at least 10 feet. Loess cover on the moraines is normally thin, except in swales. 


\section{OUTWASH DEPOSITS}

Melt water from Delta glaciers deposited great volumes of gravel which filled the Tanana Valley and some of its southern tributaries. These deposits occur as fan aprons, such as those along the front of the foothills west of Berry Creek, or appear to be closely related outwash aprons attached to piedmont moraines, such as those east of Gerstle River. However, in all occurrences the gravel has been modified by stream action or partly covered by younger outwash, alluvium, or colluvium, so that the boundaries cannot be drawn with accuracy. The deposits, although chiefly of Delta age, are designated on plate 1 as gravel, undifferentiated. The gravel is composed of light-yellowish, well-rounded, poorly sorted, and poorly stratified cobbles and pebbles of granitic rocks, schist, gneiss, quartzite, and minor amounts of mafic and ultramafic rocks, all in a matrix of sand and silt. The gravel is ironstained in the upper 3.5 feet, and distintegrated fragments occur to a depth of at least 12 feet. Loess, commonly 1 to 2 feet thick, covers the gravel.

On the western part of Macomb Plateau (fig. 9), glaciofluvial gravel forms a narrow, isolated ice-contact ridge, about 1 mile long and 100 feet high, terraced on both flanks, and composed of coarse, rounded, and washed gravel. Its isolated position on a rolling till-covered

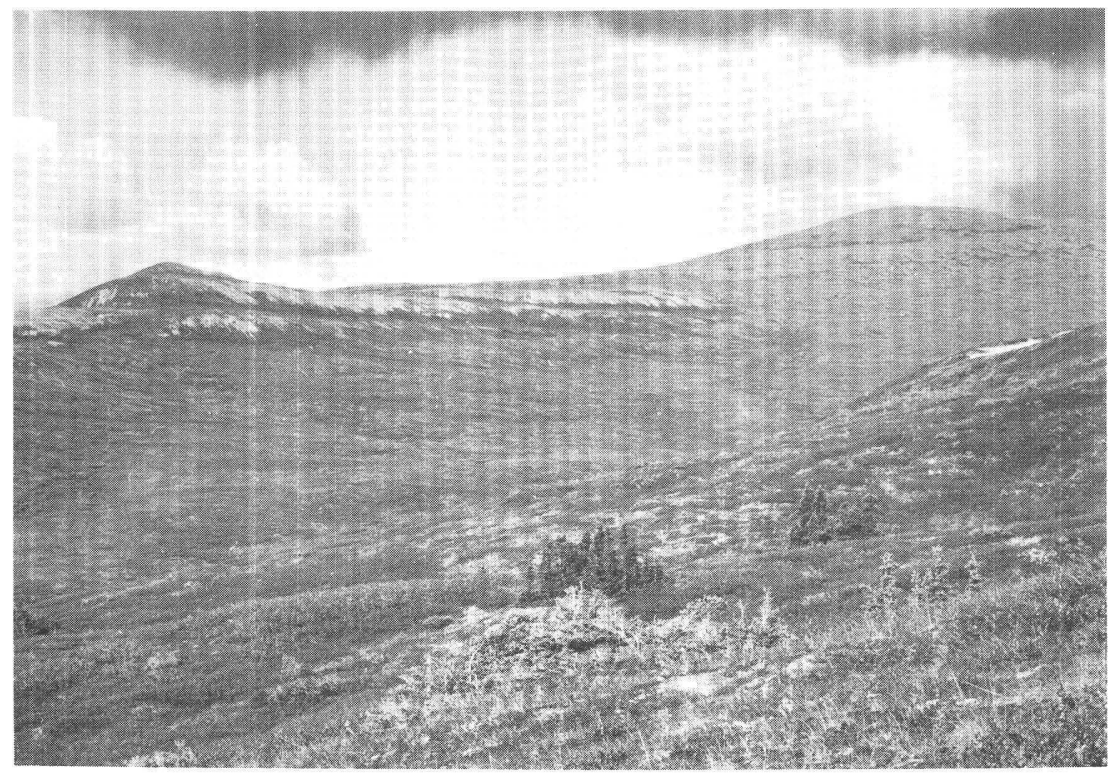

Figure 9. Ice-contact ridge on Macomb Plateau. Deposit of washed gravel with distinct terraced flanks was probably an ice-channel filling in the wasting Delta icecap. 
plateau, its composition, and its form suggest it was deposited in a large open channel in the Delta icecap during the downwasting of this glacier. Although it is possible that a small icecap of the Donnelly advance formed on the Macomb Plateau, the isolation of this gravel ridge from the inferred position of the younger icecap, or from Donnelly drift, suggests it was associated with the Delta Glaciation.

Gravel, probably of the Delta Glaciation, forms isolated terrace remnants along the Alaska. Highway west of Dot Lake and along the Tanana River northeast of this village.

\section{DEPOSITS OF THE DONNELLY GLACIATION}

\section{DISTRIBUTION}

Ice tongues of the Donnelly Glaciation moved from the high mountains as far or farther than glaciers of the earlier advance but were generally confined to valleys cut in the older till or to bedrock can-

Figure 10. Donnelly end moraine on Dry Creek. This straight, steep-fronted ridge is covered by slightly weathered boulders. Upstream the ground moraine is hummocky and typical of the terrain of Donnelly moraines. Downstream is

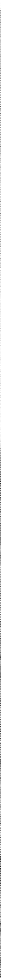


yons. The Johnson River glacier of the Donnelly advance reached and probably deflected the Tanana River (pl. 1, fig. 1) and may here have completely buried the moraine of the Delta Glaciation. In the Little Gerstle River lowland (fig. 8) and on Berry and Bear Creeks the Donnelly glaciers almost reached the outer limit of the Delta moraines (pl. 1). The large Donnelly glacier on the Robertson River to the southeast (pl. 1, fig. 1) likewise almost covered the older drift.

Donnelly ice may have formed a small plateau glacier at the head of Dry Creek. A well-formed Donnelly moraine (fig. 10), clearly separated from the Delta moraine downstream, indicates that Donnelly ice occupied this valley. The absence of a cirque at the head of this valley suggests that the Donnelly glacier flowed from a small plateau glacier. Ground moraine resembling Donnelly till lies near the head of this valley. The presence of a small Donnelly plateau glacier is also inferred from evidence for large-scale stream erosion of the Macomb Plateau. A deep branched canyon, having steep slopes and a V-shaped

a bouldery channeled outwash apron, beyond which is a more extensive and subdued moraine of the Delta Glaciation.

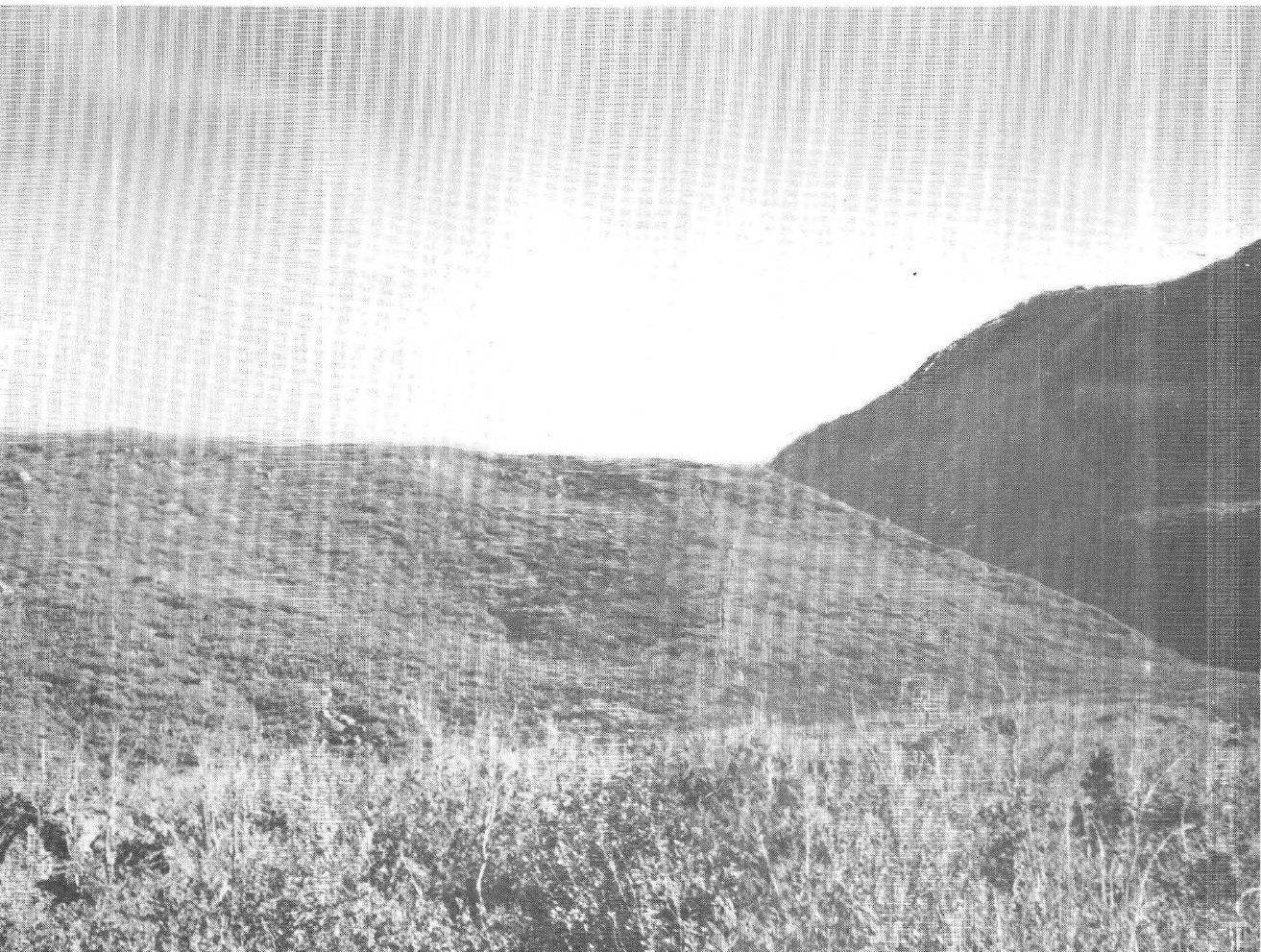


profile, has been cut in Delta till on the west edge of Macomb Plateau about 2 miles north of Prospect Creek. The stream that formed it deposited a large fan on the floor of the Johnson River valley. The small stream presently flowing out of this canyon is markedly underfit, and the drainage area is only slightly larger than the maximum dimensions of the branched canyon. This suggests that melt water from a lingering Donnelly plateau glacier formed this canyon system in late glacial time.

Elsewhere, small Donnelly moraines lie in a few cirques along the north edge of Horn Mountain, and on upper Prospect, Berry, and Bear Creeks, small, distinct end or lateral moraines are found within a few miles of the cirques. These represent short readvances during late Donnelly time.

\section{FORM}

Donnelly end moraines consist of closely spaced, steep-sided ridges, clusters of hillocks, and many depressions containing ponds or bogs. Although nearly all Donnelly moraines have been breached by existing streams, drainage on the moraines is poorly developed. Only rarely are the ponds part of a through-going drainage system, so that pond levels fluctuate markedly through the year in response to precipitation or evaporation. Donnelly moraines range in thickness from about 30 feet in the small cirques to about 300 feet for the largest moraines on the major streams.

Most Donnelly moraines are covered by large, slightly weathered, closely spaced boulders; a notable exception is the large Johnson River moraine which lies in the paths of dust storms from both the Johnson and Tanana Rivers. The blanket of loess, about 3 feet thick, has buried most boulders. Patterned ground is not common, except for ice-wedge polygons, tussocks, and hummocks, chiefly in bogs on the moraine.

\section{LITHOLOGY}

Donnelly till is composed of the local bedrock including granite, gneiss, schist, and quartzite, and minor fractions of mafic and ultramafic rocks. Most Donnelly moraine deposits consist of a mixture of these rock types. The matrix is a gray, olive-gray, or yellow-brown sandy silt. The upper 1.5 feet is weathered and contains stained and disintegrated schist, gneiss, and granitic rocks. It is mantled by 0.1 to 3 feet of loess. In a few areas, such as the valley immediately north of Prospect Creek and the small hanging cirque north of the summit of Horn Mountain, Donnelly till is composed almost entirely of granitic material. 


\section{OUTWASH DEPOSITS}

In a few areas discrete outwash aprons of the Donnelly Glaciation can be mapped, such as the apron on the north and west side of the Johnson River moraine, but elsewhere this gravel has coalesced with or blanketed older outwash or alluvium of various ages. Much of the Donnelly outwash is included in the unit designated gravel, undifferentiated, and cannot be easily distinquished lithologically or topographically from older outwash or alluvium. The reason for this is that after the deposition of Delta outwash aprons, which, as stated, coalesced with contemporaneous nonglacial fan deposits, major trenching did not occur because of the loss of volume and competence of the streams as they emerged from the mountains and filtered into the gravel of the Tanana Lowland. During the next major episode of deposition, the Donnelly advance, melt water reworked the older outwash before burying it with sheets of gravel and obscuring preexisting channels. Flights of terraces were not formed, and the result was a composite deposit similar to an alluvial fan or fan apron.

\section{LATE DONNELLY GLACTAL ADVANCE}

In the upper Prospect, Berry, and Bear Creek valleys, lateral and end moraines are within a few miles of the present glaciers (pl. 1). The lateral ridges have smooth profiles, are commonly discontinuous, and terminate in crescentic end moraines that have been breached by present streams. They are covered by slightly weathered boulders and tundra vegetation and have been weathered to depths of 0.5 to 1 foot. These characteristics suggest they are Pleistocene rather than Recent in age; they are, therefore, tentatively correlated with a minor late Donnelly advance. Evidence for such an advance appears in some but not all valleys in the vicinity (Holmes and Péwé, 1965; Holmes, 1965).

\section{DEPOSITS OF RECENT GLACIERS}

Small end moraines lie against existing glaciers at the head of Prospect, Berry, and Bear Creeks. Similar moraines occur in cirques now free of ice, for example, at the head of the valley immediately north of Prospect Creek.

These moraines consist of one or more steep-sided bouldery ridges (figs. 11, 12). Some moraines enclose small ponds or dry depressions; most have been only slightly eroded by melt-water streams. Some moraines have moved or are moving downslope and consequently have developed the characteristic crescentic surface ridges typical of rock glaciers (see pp. 35-37). The boulders are closely spaced, unweathered or very slightly weathered, and are commonly unstable. Vegetation is sparse or absent. 


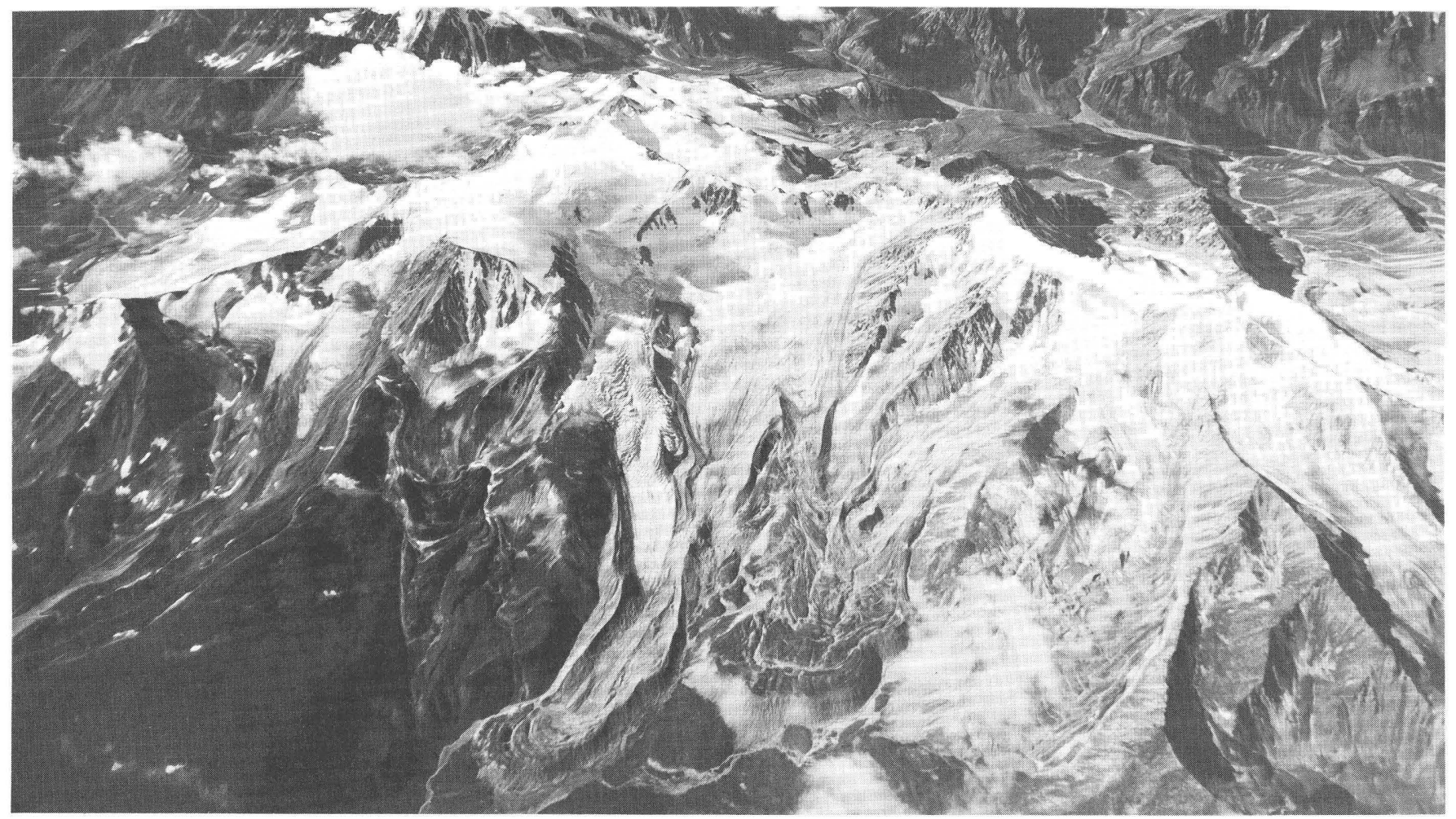

FIGURE 11. Oblique aerial photograph of Recent moraines and rock glaciers in the upper Bear Creek area. View to the south. U.S. Army Air Force photograph, 1941. 
The moraines are composed mostly of granitic fragments and minor amounts of gneiss and schist. The matrix is a compact gray, sandy silt; the till has no weathering profile.

The appearance of these moraines and their association with existing glaciers indicate they represent advances in Recent time. Similar moraines occur throughout the Alaska Range and in many alpine areas of North America.

\section{FROST ACTION AND MASS MOVEMENT}

\section{ROCK GLACIERS}

Rock glaciers are conspicuous features in the Johnson River area, as they are in the central Alaska Range (Wahrhaftig and Cox, 1959), in the Wrangell Mountains (Capps, 1910), and elsewhere in the mountains of interior Alaska. Most of those in the Johnson River area appear to originate mostly from Recent moraines; it is difficult, therefore, in the absence of deep and extensive excavations, to map their upper boundaries. The inferred boundaries shown are based on surface indications. Wahrhaftig and Cox (1959, p. 418) suggest that the zone of conical pits in the debris marks the head of the rock glacier. Another indication is the upper limit of crescentic furrows, extension fractures, and other surface signs of movement.

All rock glaciers mapped share the general characteristics of those reported elsewhere in the Alaska Range. They are covered with large angular blocks which rest on a thick layer of smaller boulders, pebbles, sand, and silt. Their surfaces are marked by crescentic ridges and furrows, bowed in a downslope direction (fig. 13), and by longitudinal ridges. The surface boulders are encrusted with lichens, and the frontal slope is steep and exposes bare unweathered debris (fig. 12). No rock glacier was observed that had a distinct wall of debris facing upslope and separating it from the true end moraine; this is a common feature of rock glaciers in the Nenana River area to the west (Clyde Wahrhaftig, written commun., 1962). The material resembles till but also contains products of rockfall, frost action, and abrasion of moving debris along the valley.

The rock glacier in the southwestern part of the area (frontispiece) is of particular interest because it has unusual length, it terminates below the tree limit but has forest vegetation as well as shrub and tundra plants on its upper surface, its forward motion can be observed, and it is an example of a rock glacier composed of both morainal material and talus.

The debris feeding this rock glacier originates at the lower end of a small glacier in the Mount Hayes C-2 quadrangle, at an altitude of about 5,850 feet. It extends 3 miles to the east on a fairly even gradient 
to the terminus at about 3,000 feet. The maximum width is about 0.4 mile, and the minimum thickness is estimated at 150 feet.

This rock glacier is composed mostly of light-yellowish granitic debris having minor constituents of mafic rocks. The frontal slope (fig. 14) exhibits the characteristic line dividing the moving upper part from the lower talus sheet, which is derived from the moving wall of debris.

The lower part of the top surface is covered by vegetation (fig. 14), including scattered tundra plants; birch, alder, and aspen shrub; and spruce trees. The vegetation is growing on a thin patchy soil containing peat. The spruce trees grow on the rock glacier surface to an altitude of about 3,100 feet, the approximate tree limit on the valley sides nearby. Based on tree-ring counts, the age of the largest spruce trees is about 150 years. Shrub vegetation grows to an altitude of about 3,400 feet.

The movement of the front of the rock glacier can be observed at times. In June 1960, boulders and smaller fragments were sliding down the bare front at intervals of 1 or 2 minutes, freshly uprooted trees from the upper surface were seen on the advancing front, and trees in the path of the rock glacier were freshly gouged by sliding rocks. The north side of the rock glacier about half a mile from the snout has recently moved laterally as indicated by the exposure of unweathered debris on the flanks and encroachment of boulders over the tundra vegetation.

Most of this rock glacier appears to be derived from morainal material, as indicated by the till-like composition of the moving front and by the upslope merger with a Recent moraine of a small existing glacier. However, the large talus fans on the south valley wall con-

FIGURE 12. Southeast view of Recent moraine at the head of Bear Creek. Unlike the rock glaciers in the vicinity, the front of this moraine is compact and is not moving. Photographed in July 1960. 
tribute some debris at present, as shown by the encroachment of fresh talus over the weathered boulders of the south flank of the rock glacier. The degree of encroachment is minor within the mapped area but becomes increasingly important near and west of the map boundary.

The volume of the rock glacier, its relationship to a Recent moraine, and the weathered surface boulders suggest it was formed several hundred or several thousand years ago. The establishment of a mature stand of trees on its surface suggests that it may have become inactive. However, the current encroachment of fresh talus on the surface of the glacier, the actively moving front and flanks, and the disruption of its surface vegetation suggest that it has recently been reactivated.

\section{TALUS}

Sheets, stripes, and fans of angular frost-riven talus fragments have accumulated on steep valley and cirque walls in the mountains and foothills. Only the larger talus sheets are shown on the map; thin, discontinuous sheets and narrow stripes of talus mantle nearly all the steep slopes at higher altitudes. Most of the larger accumulations occur on granitic slopes, such as along Prospect Creek and on the south side of the large rock glacier. Two generations of talus slopes are evident: old talus, having weathered blocks covered by lichens, and modern unstained and lichen-free talus, forming under present climatic conditions. A few small talus sheets beyond the glacial limit may date from the earliest glaciation, but most old talus probably formed since the Donnelly advance. The latest renewal of talus forma-

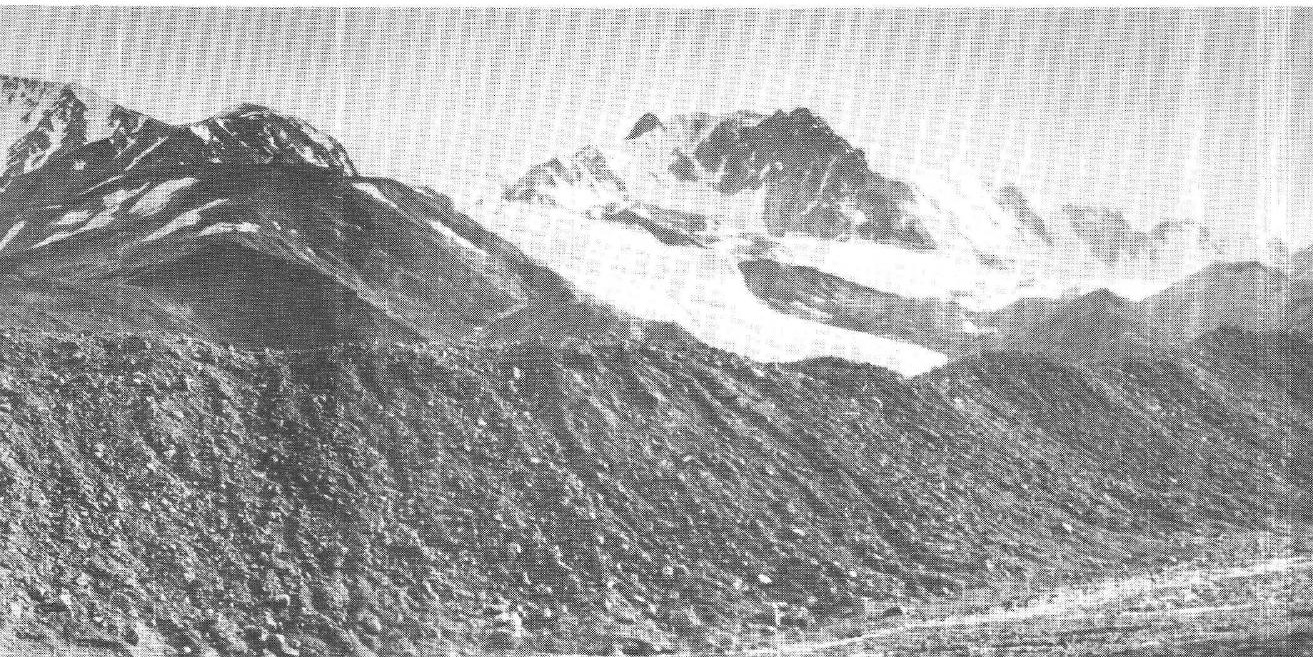




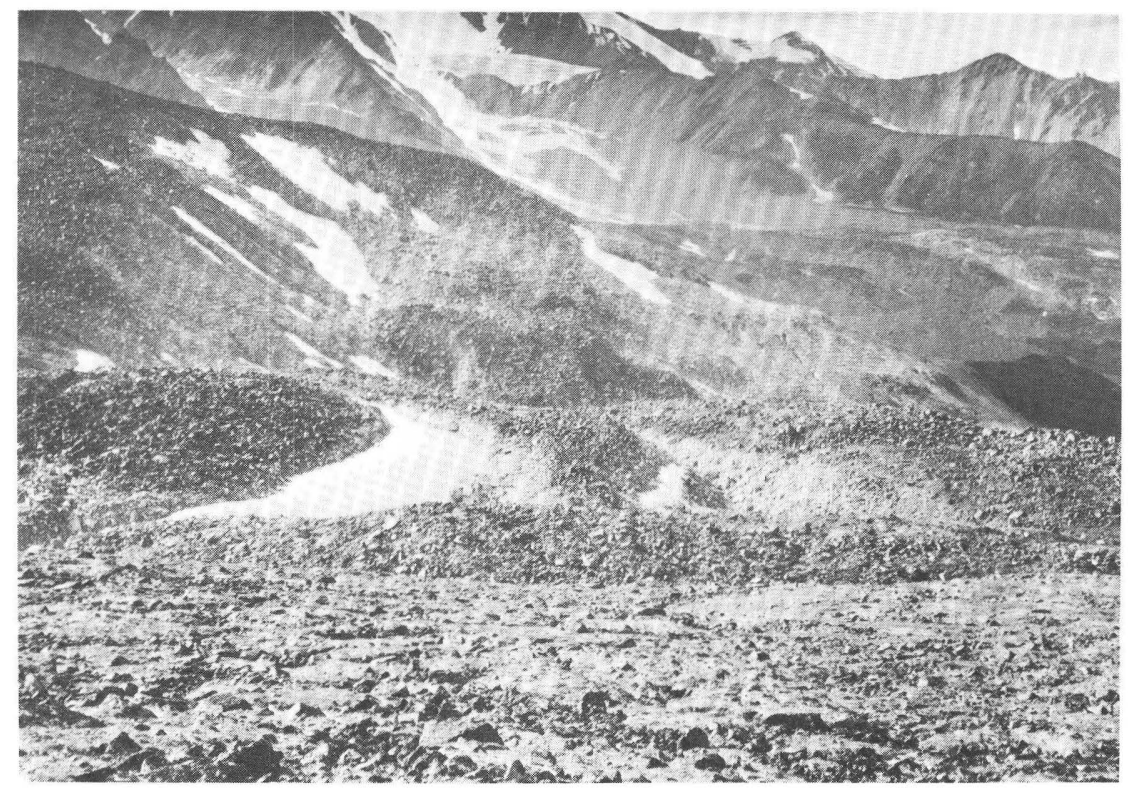

Figure 13. Crescentic ridges and furrows. Lingering snow patches in the furrows retarded the growth of lichens and created a clear pattern of light-colored swales and somber-colored transverse ridges. Near the terminus of a small reactivated rock glacier on a tributary to Bear Creek in the southwest corner of the Mount Hayes C-2 quadrangle. Photographed in July 1960.

tion possibly coincided with the reactivation of the large rock glacier in the southwest part of the area.

\section{RUBBLE}

Debris, formed from local bedrock sources by frost action and not transported any significant distance, mantles the upland surfaces of the unglaciated foothills or glaciated surfaces that have not been ice covered since the Delta advance. The best developed rubble fields are on Horn Mountain, Macomb Plateau, and Knob Ridge and are underlain mostly by granitic rocks. On Horn Mountain rubble lies on low eminences on the periphery of this plateau. Frost action has formed patterned ground features, including segregated rings, nets, loops, and stripes, or nonsegregated steps, lobes, spot medallions, and hummocks. Rubble on Horn Mountain has formed since the Delta Glaciation. Freshly upturned boulders and broken turf in the centers of segregated rings indicate frost processes are still active. On Knob Ridge rubble blocks are very large; some are arranged in faint patterns. The blocks are lichen covered, and in places shrub or tree vegetation which has become established among the blocks indicates that 


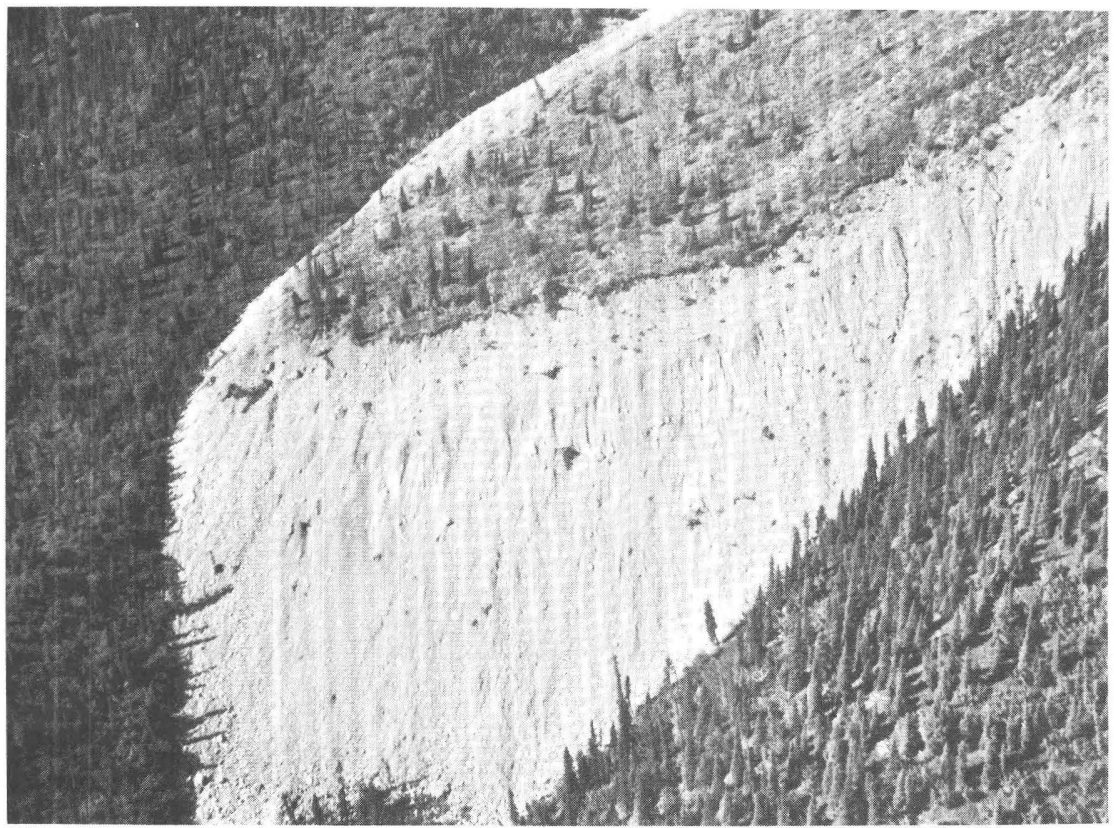

Figure 14. Moving front of the large rock glacier. Spruce trees growing on the upper surface occur as high as the local tree limit on the adjacent valley sides. Recently toppled trees lie on the moving front. The upper edge of the talus sheet can be seen faintly, above which is the most rapidly moving part of the rock glacier. Boulders were observed sliding and bouncing down the face in June 1960. Photographed in August 1961.

the rubble is not actively forming at this locality now. Rubble here may have formed at any time, except the present, since or before the earliest glaciation.

\section{COLLUVIUM}

Undifferentiated colluvium.-Broad sheets of gravity-moved debris, consisting of varied mixtures of loess, rubble, alluvium, and bedrock fragments, cover the sloping upland surfaces of some unglaciated foothills. The most extensive sheets rest on Independent Ridge and on the prominent hill northwest of Fish Lake. Downslope movement of colluvium is clearly indicated by the prominent solifluction lobes on Independent Ridge. Colluvium has been forming since or before the earliest recorded glaciation in this area.

Colluvial till.-Modified ground moraine mixed with loess, rubble, alluvium, outwash, and possibly other till occurs on the steep walls of the upper Johnson River valley and the Little Gerstle Lowland, on the glaciated summit of Horn Mountain, and in upper Dry Creek valley. Colluvial till may occur as smooth sheets, such as those on 
steep valley sides; it may exhibit patterned ground features, such as segregated nets and circles or stripes and steps; or it may occur as nonsegregated hummocks, spot medallions, and soil stripes, such as those on the summit of Horn Mountain. Because this material has been mixed with others, it cannot be mapped as ground moraine; and because it may consist of ground moraine of more than one age, it cannot be assigned to a single glaciation. Although the basic constituent is till, it normally contains more silt and angular fragments than normal morainal material. The age of the material ranges from the Delta Glaciation to the Recent.

\section{PINGOS}

Two pingos have been identified in the mapped area, and two other large mounds have been tentatively identified as pingos. Pingos are generally believed to be the result of movement of ground water upward or laterally in or just above the permafrost to a point where large ice lenses form and the overburden is lifted.

The best formed pingo (figs. 15, 16) in the mapped area is about 4.5 miles east of Sand Lake, in a minor valley tributary to the Tanana River. It is immediately north of the break in slope between the loess-

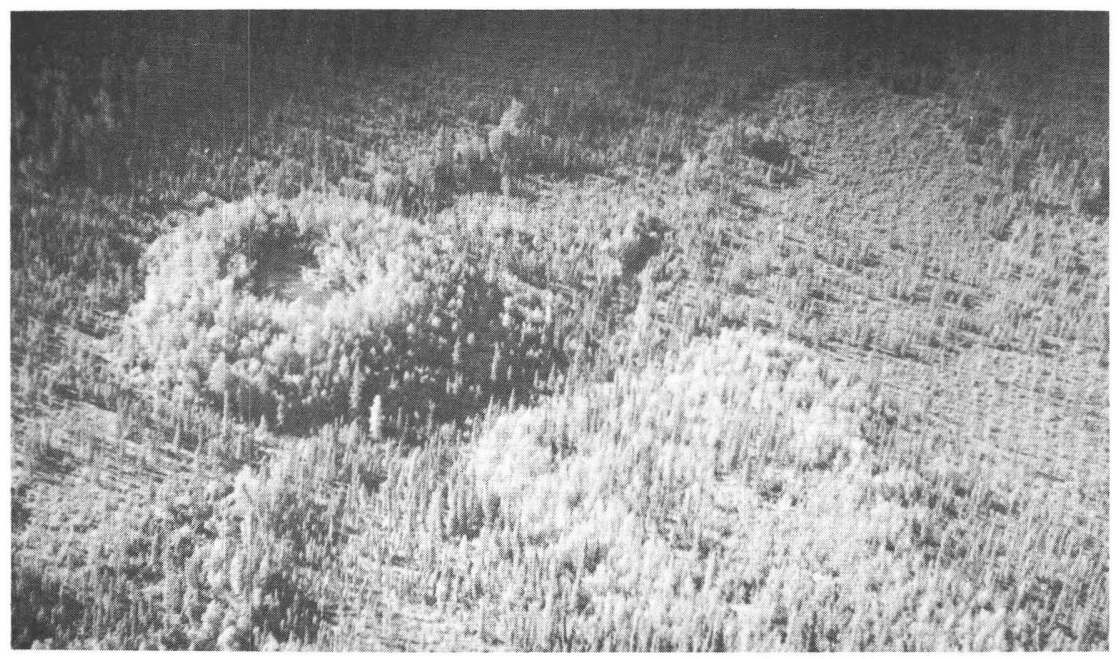

Figure 15. Circular cratered pingo east of Sand Lake. The nearly symmetrical mound, about 46 feet high, having a pond in the crater stands out clearly above the surrounding muskeg. A moderately dense stand of birch and a few white spruce grows on its flanks and rim and reflects better soil drainage than the surrounding black spruce muskeg. Shores of the pond are obscured by leaning trees that move down on slump blocks on the inner slopes of the crater. The outlet, dry in midsummer, is on the right side of the picture. Photographed in August 1960. 


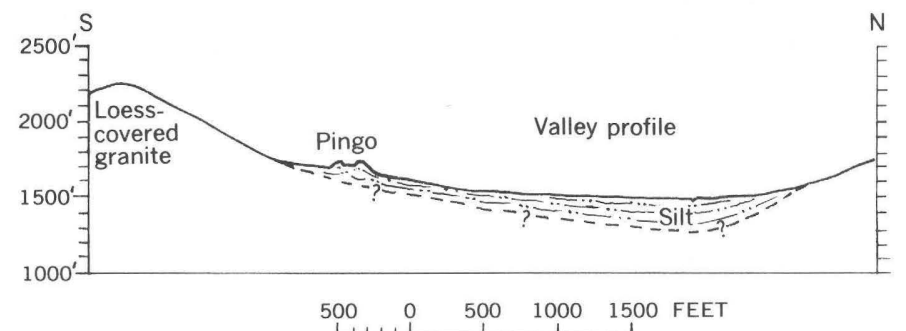

曷

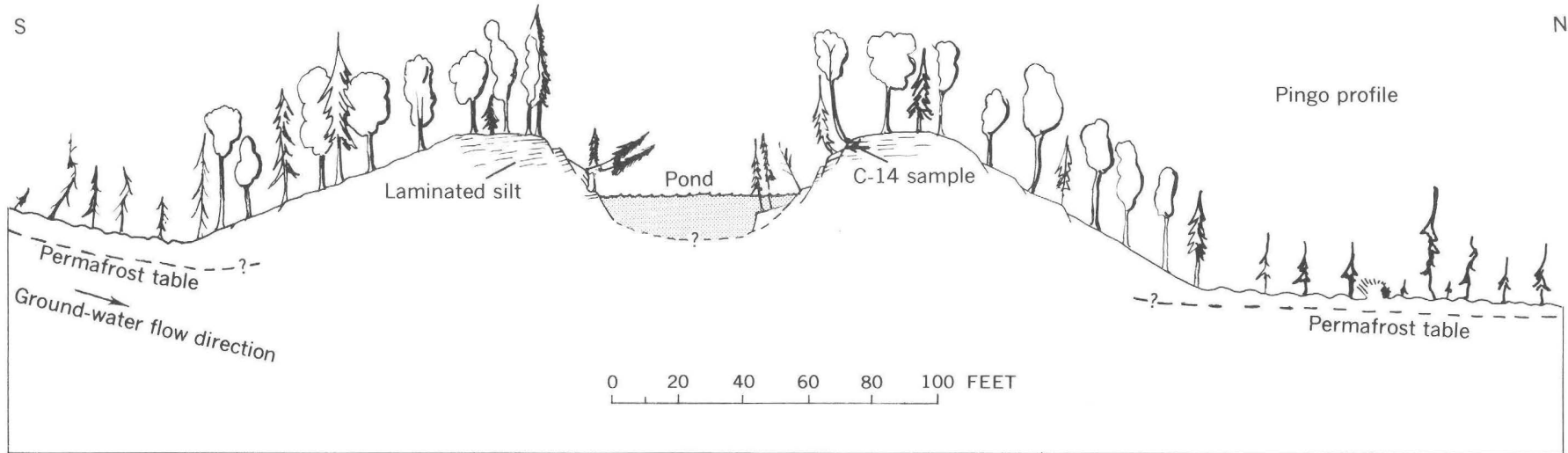


covered bedrock valley side and the silt-filled valley floor. The valley floor is covered with black spruce muskeg vegetation which grows on saturated organic silt overlying a shallow permafrost table. The height of the pingo is 46 feet, and its diameter at the base is about 310 feet. It is nearly symmetrical in plan and has in the crater a circular pond, which at times drains through a narrow outlet on the west. The grade of the slopes ranges from $20^{\circ}$ to $30^{\circ}$. The crater sides are actively slumping; blocks of silt, some having trees on them, have slid toward the pond. The outer slopes are also fractured, but downslope movement of blocks is minor. The pingo is covered by birch and white spruce trees as much as 6 inches in diameter at breast height and a turf mat of moss, sedge, and heath plants. The upper 18 feet of the pingo, as shown in the exposed sides of the crater, is composed of light-graybrown laminated sandy silt having scattered angular fragments of granitic rock; most are as much as 4 inches in diameter, but a few are as much as 1 foot across. Gently inclined lenses of arkosic sand, thin layers of peat, and lenticular orange mottlings show that the bedding of the pingo dips radially. A fragment of spruce collected from the silt at a depth of 2.5 feet on the north rim of the crater yielded a radiocarbon age of 7,010 \pm 150 years B.P. (Reidar Nydal, Norwegian Institute of Technology, Trondheim, written commun., 1961, sample T-303). That the upper 3 to 5 inches of the silt is stained brown indicates a weakly developed subarctic Brown forest soil profile. As a well-developed subarctic Brown forest soil may form in less than 4,000 years in this area (Holmes and others, 1966), the age of the pingo is probably no greater than a few thousand years.

A smaller pingo, 1.3 miles southwest of Dot Lake village and in a similar environment, is on the edge of silt-filled, unglaciated valley at the foot of a loess-covered granitic slope. Its maximum height is about 25 feet, and it is about 100 feet in diameter at the base. The vegetation consists of small spruce and alder shrub, and aspen trees as much as 1 foot in diameter. Muskeg vegetation grows on the valley floor around the pingo. The pingo is composed of sandy silt. In a collapse depression at the summit, a subarctic Brown forest soil is exposed; the typical reddish-brown horizon is at a depth of 1.2 to 2 feet. Such a soil profile can develop in this area on well-drained silt younger than the Donnelly Glaciation. This soil profile suggests that this pingo is older than the one described previously.

A pingolike mound, about 2.5 miles west of Sand Lake and identified from the air as well as from aerial photographs, is about 30 feet high, 300 feet in diameter, and covered by birch and spruce trees. Like the pingos visited, it lies in a muskeg near the edge of a silt-filled valley. Another pingolike mound, identified on aerial photographs 
and of the same dimensions as the foregoing hillock, lies near the edge of a muskeg 1.3 miles northwest of the northwest arm of Lake George.

The pingos in the mapped area are representative of several hundred pingos identified in central Alaska (Holmes and others 1963, 1966) and are the open-system type as defined by Müller (1959).

\section{PATTERNED GROUND}

Geometric soil patterns are common on till, colluvium, and rubble, as mentioned in foregoing sections on these deposits. At present, active movement and formation of patterned ground occurs only above altitudes of 4,800 feet, as on Horn Mountain. The most distinct segregated patterns are in material derived largely from granitic sources (fig. 17). Geometric forms on surficial material derived from schist, for example on Independent Ridge, are nonsegregated hummocks or lobes.

At lower altitudes, hummocks and tussocks are widely distributed, especially in bogs and muskegs. Frost-wedge or frost-crack polygons are present in only a few bogs at lower altitudes. Well-formed polygonal furrows in bare outwash gravel of Donnelly age are typical large-scale frost features in the nearby Delta River district (Holmes

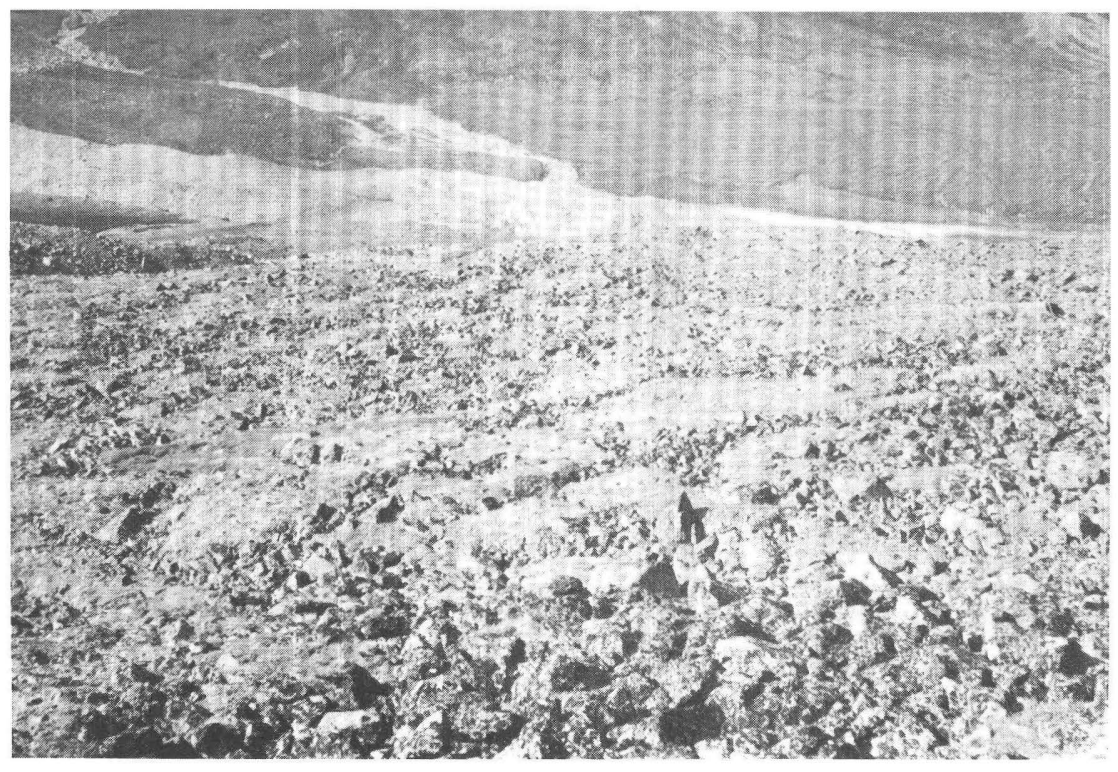

FIGURE 17.-Net of segregated boulders in till. This rare occurrence of patterned ground is near the head of Bear Creek on flat ground moraine at an altitude of about 5,500 feet. Unit mesh is about 5 to 8 feet in diameter. Photographed in July 1960. 
and Benninghoff, 1957, p. 112) but were not observed in this area. Here the nearly continuous mantle of loess and silt and the deeper snow cover may have inhibited formation of patterned ground in gravel.

\section{ALLUVIAL DEPOSITS}

\section{ALLUVIAL SILT}

Fine alluvium lies in nearly all valleys of the Yukon-Tanana Upland and unglaciated foothills in the mapped area. These valley-filled deposits are nearly flat, covered mostly by bogs and muskegs, marked by ponds and a few pingos, and slightly incised by narrow streams. They merge upslope with colluvial aprons and loess (both unmapped) and terminate on the downstream edge in low scarps along the streams. The deposits are composed of poorly to well-stratified brown, gray, or black sandy silt, having variable amounts of peat and scattered bedrock fragments. They are derived largely from loess and weathered schist or granite.

Deposition of the alluvial silt has probably taken place continuously since the earliest glacial advance. Radiocarbon dating of wood in the upper layer of alluvial silt in a pingo shows that deposition was taking place as late as 7,000 years ago. Incision of these deposits by modern streams and formation of a scarp dividing the silt deposits from the low terrace of the Tanana River indicate that deposition at the present is minimal and probably is confined to mass movement along the lateral borders of the deposits.

\section{TERRACE DEPOSITS}

Nearly continuous low terraces lie along the Tanana River and in the lower valleys of some of its southern tributaries. They are 10 to 20 feet above the river, as much as 30 feet below the outwash terraces, and about 10 feet below the nonglacial alluvial silt deposits. These terraces are easily distinguished from outwash or alluvial silt deposits by meander scars; they are also marked by shallow boggy depressions filled with organic deposits, tributary channels, and silt-covered sand dunes. Only the largest areas of organic deposits are shown on plate 1; many smaller areas of silt and peat occur on these terraces.

The terraces are composed of as much as 16 feet of laminated sandy silt having layers of peat overlying poorly sorted gravel, some of which contains rounded boulders. The underlying gravel is interpreted as older outwash gravel that was not scoured below the present stream level. As these terraces lie below and against outwash terraces of the Donnelly Glaciation, they are probably Recent in age. These extensive deposits constitute the best forest land in the mapped area. Small but 
exploitable stands of white spruce grow on the terraces near the banks of the larger rivers.

\section{ALLUVIAL FANS}

Individual and coalescent alluvial fans occur throughout the area. The most extensive of these flank Independent Ridge and fill the Gerstle River lowland to the west. Another large group of fans is on the east side of the Johnson River and north of Prospect Creek. These fans were largely derived from the deep canyon cut in the Macomb Plateau.

Fans are composed of locally derived fragments of angular bedrock or till and are typically poorly stratified and sorted. Most are covered with loess and turf. Nearly all fans lie in canyons or on slopes covered by Donnelly glaciers; hence, their age is late glacial or Recent. As nearly all fans are gullied, the major phase of fan accumulation has apparently given way to dissection.

\section{FLOOD-PLAIN DEPOSITS}

Alluvium is exposed on the surface of active flood plains of most of the mountain streams and the Tanana River. On the Gerstle, Johnson, and Tanana Rivers, alluvium occurs as islands surrounded by braided channels. These channels shift laterally during the warm season; hence, the distribution of alluvium shown on the map is merely suggestive of their pattern and represents only the occurrence at the time the base-map data were compiled. On the larger streams the flood-plain gravel is incised by dry channels and is mantled by migrating sand sheets. The alluvium consists of glacial silt, sand, well-rounded gravel, and boulders; it is poorly sorted and irregularly stratified. Parts of the flood plain are covered by overflow icings in winter. In summer, silt is blown from the flood plains and deposited as loess on the terraces and nearby moraines.

\section{ORGANIC DEPOSITS}

Alluvial, eolian, and lacustrine silt mixed with peat and finely divided organic material occurs throughout the area in swales on summits of the foothills, in kettles and channels on the moraines, in channels cut into coarse gravel along the foot of the mountains, in channels and lake depressions on the low terrace along the Tanana River, and in the valleys of the unglaciated hills north of the river. The surface of these deposits is commonly marked by earth hummocks or sedge tussocks, and bog or marsh vegetation is characteristic.

The silt is well stratified, well sorted, poorly consolidated, and light brown to black. Depending on drainage, weathering may produce a mottled gray and brown Half Bog soil or a black Bog soil. 
Organic silt has been accumulating continuously since or before the Delta Glaciation. Younger silt rests in swales on Donnelly moraines and outwash or on post-Donnelly terrace deposits and alluvial silt deposits.

\section{BEACH RIDGES}

Well-formed gravel ridges lie along the edges of Lake George, Twelvemile Lake, and Moosehead Lake. The ridges are continuous, except on the most precipitous shores. Normally more than one persistent ridge is present-in places as many as six-from 2 to 15 feet above the shoreline. Most are composed of unstratified sand and wellrounded gravel, but some consist of silt or organic silt.

The terraces are formed by the movement of lake ice during breakup and by thermal expansion of the ice in winter. The gravel ridges make relatively good sites for vacation cottages, as they provide good foundations, are adjacent to the best sand beaches, and provide good drainage for disposal of waste.

\section{EOLIAN DEPOSITS}

\section{SAND DUNES}

The largest sand dunes occur near the lower Gerstle River; these are in the form of ridges as much as 15 feet high and 3 miles long and are oriented in a northwest-southeast direction. They are composed of yellow to light-gray, well-sorted, crossbedded sand, and most are covered by 1 to 3 feet of loess. These dunes rest on the low terrace deposits, which are post-Donnelly in age. The loess and vegetation cover show that they are not being formed at present.

Formless tree-covered sand sheets lie along the Alaska Highway west of the Gerstle River. These deposits are typically less than 10 feet thick and contain shallow dry depressions and ponds. The sand is medium yellow, well sorted, and crossbedded. These deposits cannot be outlined on aerial photographs and do not appear on the map; however, a hint of their general distribution is the occurrence of the small dry or pondfilled depressions.

Small sand sheets are moved by the wind across the flood plains of the Gerstle and Johnson Rivers. These deposits, which are not mapped, are as much as 5 feet high and may be 30 to 50 feet across. They are composed of fresh gray sand derived from the flood plain.

Formless blowouts composed of well-sorted sand occur on the north side of the deep branched canyon on the west edge of Macomb Plateau. The sand appears to be derived from the bare till slopes of the canyon and probably was deposited in cliff-head dunes. The age is probably late glacial. 


\section{LOESS}

Loess is widely distributed and is especially thick on the moraines near the Johnson and Little Gerstle Rivers and on the bedrock hills north and south of the Tanana River. It is not mapped. Loess thickness is typically 1 to 3 feet, the greatest thicknesses being along the banks of the major rivers. The loess is a light-brown, faintly stratified, wellsorted sandy silt. In well-drained localities a reddish-brown subarctic Brown forest soil has developed; in poorly drained areas a mottled gray and brown Half Bog soil has formed. Loess has been deposited from the times of Delta Glaciation to the present. Reworked loess occurs in organic silt, alluvial silt, terrace deposits, and colluvium, all which are shown on the map.

\section{SUMMARY OF GEOLOGICAL HISTORY}

In Precambrian (?) time a very thick sequence of sedimentary rocks was deposited and later metamorphosed, faulted, and folded. The intensity of metamorphism and deformation was sufficient to obscure nearly all vestiges of original structure and stratification. These rocks, here identified as the Birch Creek Schist, probably were elevated and eroded before the next younger rocks were deposited. Although P.uleozoic and Mesozoic rocks are not preserved in the mapped area, their occurrence elsewhere in the Alaska Range testifies to a long sequence of sedimentation (Capps, 1940, p. 130-131).

Deformation and batholitic intrusion of the Alaska Range occurred at intervals during Cretaceous time (Payne, 1955), and at least some of the granitic rocks in the mapped area were emplaced then. Later, the mountains were eroded to a low relief. In Eocene time clay, silt, gravel, and coal were deposited in nearby local basins (Wahrhaftig, 1958 , p. 10), such as near Jarvis Creek west of the mapped area (Wahrhaftig and Hickcox, 1955). In late Tertiary time the coal-bearing formation was deformed, and the associated uplift of the Alaska Range resulted in the deposition of the Nenana Gravel (Moffit, 1954, p. 183). Carbonaceous silt and clay beds were also deposited in local basins, such as those which formed near the Johnson River.

The most recent elevation and the creation of major drainage systems of the Alaska Range occurred before the Delta Glaciation. Glaciers at that time flowed from high cirques and formed icecaps on several of the flat-topped foothills, such as Horn Mountain and Macomb Platea.u. Most of the large valley glaciers of this advance developed into piedmont ice tongues and deposited broad moraines on the floor of the Tanana lowland. However, there is evidence that a glacier reached the mouth of the Johnson River during the Delta Glaciation. During this glaciation several discrete outwash plains were formed, some of 
which merged with gravel from nonglacial mountain streams. This outwash probably was graded to nonglacial silty alluvium from the Yukon-Tanana Upland.

The Donnelly Glaciation was almost as extensive as the Delta advance in the major valleys but was appreciably less extensive on the upland surfaces. In the Johnson River valley, Donnelly ice moved at least to the banks of the Tanana River and may have deflected the river toward Lake George. Donnelly outwash deposits are restricted to small aprons and terraces near the major end moraines; other gravel of Donnelly origin is coalescent with older glacial outwash and with nonglacial gravel. A late advance, probably a readvance of Donnelly glaciers, has been recorded in a few high, well-sheltered valleys, and modern glaciers in Recent time have formed moraines in several high cirques.

The deposition of organic silt, eolian sand, loess, alluvial fans, and flood-plain deposits, and the formation of talus, rubble, colluvium, low terraces, pingos, rock glaciers, and beach ridges, although not reflecting in all cases events so distinct as glaciations, have continued to play important roles in the modification of the landscape throughout the late Pleistocene and into the Recent. The varying intensity of talus formation and the development of rock glaciers are probably reflections of climatic fluctuations in post-Wisconsin time.

\section{REFERENCES}

Benninghoff, W. S., and Holmes, G. W., 1961, Preliminary report on upper Cenozoic carbonaceous deposits in the Johnson River area, Alaska Range [abs.], in Raasch, G. O., ed., Geology of the Arctic: Toronto, Univ. Toronto Press, v. 1, p. 599.

Brooks, A. H., 1900, A reconnaissance of the White and Tanana River basins, Alaska, in 1898: U.S. Geol. Survey 20th Ann. Rept., pt. 7, p. 425-494.

Capps, S. R., 1910, Rock glaciers in Alaska: Jour. Geology, v. 18, p. 359-375. 1940, Geology of the Alaska Railroad region: U.S. Geol. Survey Bull. 907, $201 \mathrm{p}$.

Foster, H. L., and Holmes, G. W., 1965, A large transitional rock glacier in the Johnson River area, Alaska Range: U.S. Geol. Survey Prof. Paper 525-B, p. B112-B116.

Holmes, G. W., 1959, Glaciation in the Johnson River-Tok area, Alaska Range [abs.] : Geol. Soc. America Bull., v. 70, p. 1620.

1965, Geologic reconnaissance along the Alaska Highway, Delta River to Tok Junction: U.S. Geol. Survey Bull. 1181-H, 19 p.

Holmes, G. W., and Benninghoff, W. S., 1957, Terrain study of the Army Test Area, Fort Greely, Alaska: Washington, D.C., U.S. Geol. Survey, Military Geology Br., v. 1, 287 p. ; v. 2, maps.

Holmes, G. W., Hopkins, D. M., and Foster, H. L., 1963, Pingos in central Alaska [abs.] : Geol. Soc. America Spec. Paper 73, p. 173. 
Holmes, G. W., Hopkins, D. M., and Foster, H. L., 1966, Distribution and age of pingos of interior Alaska, in Proceedings, Permafrost International Conference, Lafayette, Indiana, 1963 ; Natl. Acad. Sci. Pub. 1287, p. 88-93.

Holmes, G. W., and Péwé, T. L., 1965, Geology of the Mount Hayes D-3 quadrangle, Alaska : U. S. Geol. Survey Geol. Quad. Map GQ-366.

Hopkins, D. M., Karlstrom, T. N. V., and others, 1955, Permafrost and ground water in Alaska: U. S. Geol. Survey Prof. Paper 264-F., p. 113-146.

MacNeil, F. S., and others, 1961, Correlation of Tertiary formations of Alaska : Am. Assoc. Petroleum Geologists Bull., v. 45, p. 1801-1809.

Mertie, J. B., Jr., 1937, The Yukon-Tanana region, Alaska: U. S. Geol. Survey Bull. 872, 276 p.

Moffit, F. H., 1954, Geology of the eastern part of the Alaska Range and adjacent area : U.S. Geol. Survey Bull. 989-D, p. 63-218.

Müller, Fritz, 1959, Beobachtungen über Pingos: Medd. om Grønland, v. 153, no. $3,127 \mathrm{p}$.

Payne, T. G., 1955, Mesozoic and Cenozoic tectonic elements in Alaska: U.S. Geol. Survey Misc. Geol. Inv. Map I-84.

Péwé, T. L., 1952, Preliminary report of multiple glaciation in the Big Delta area, Alaska [abs.] : Geol. Soc. America Bull., v. 63, p. 1289.

Péwé, T. L., and Holmes, G. W., 1964, Geology of the Mount Hayes D-4 quadrangle, Alaska: U.S. Geol. Survey Misc. Geol. Inv. Map I-394.

Péwé, T. L., and others, 1953, Multiple glaciation in Alaska, a progress report: U.S. Geol. Survey Circ. 289, 13 p.

U.S. Geological Survey, 1957, Compilation of records of quantity and quality of surface waters of Alaska, through September 1950: U.S. Geol. Survey Water-Supply Paper 1372, 262 p.

1958a, Quantity and quality of surface waters of Alaska, October 1950 to September 1953: U.S. Geol. Survey Water-Supply Paper 1466, 243 p.

1958b, Quantity and quality of surface waters of Alaska, October 1953 to September 1956 : U.S. Geol. Survey Water-Supply Paper 1486, 229 p.

1960, Quantity and quality of surface waters of Alaska, 1957: U.S. Geol. Survey Waiter-Supply Paper 1500, 100 p.

U.S. Weather Bureau, 1958, Climatic summary of Alaska-Supplement for 1922 through 1952 : U.S. Weather Bur., Climatography of the United States No. $11-43,39 \mathrm{p}$.

1959, Climatological data, Alaska, annual summary, 1958: v. 44, p. 194-203.

Wahrhaftig, Clyde, 1958, Quaternary geology of the Nenana River valley and adjacent parts of the Alaska Range: U.S. Geol. Survey Prof. Paper 293-A, $68 \mathrm{p}$.

- 1965, Physiographic divisions of Alaska: U.S. Geol. Survey Prof. Paper $482,52 \mathrm{p}$.

Wahrhaftig, Clyde, and Cox, Allan, 1959, Rock glaciers in the Alaska Range: Geol. Soc. America Bull., v. 70, p. 383-436.

Wahrhaftig, Clyde, and Hickcox, C. A., 1955, Geology and coal deposits, Jarvis Creek coal field, Alaska : U.S. Geol. Survey Bull. 989-G, p. 353-367.

Wasserburg, G. J., Eberlein, G. D., and Lanphere, M. A., 1963, Age of the Birch Creek Schist and some batholithic intrusions in Alaska [abs.]: Geol. Soc. America Spec. Paper 73, p. 258-259. 
